\title{
Redox Regulation and Oxidative Stress in Mammalian Oocytes and Embryos Developed In Vivo and In Vitro
}

\author{
Madeleine L. M. Hardy, Margot L. Day $*,+(\mathbb{D}$ and Michael B. Morris $*,+(\mathbb{D}$ \\ Discipline of Physiology, School of Medical Sciences, Faculty of Medicine and Health, University of Sydney, \\ Sydney 2006, Australia; mhar7073@uni.sydney.edu.au \\ * Correspondence: margot.day@sydney.edu.au (M.L.D.); m.morris@sydney.edu.au (M.B.M.) \\ † M.L.D. and M.B.M. are joint senior authors.
}

Citation: Hardy, M.L.M.; Day, M.L.; Morris, M.B. Redox Regulation and Oxidative Stress in Mammalian Oocytes and Embryos Developed In Vivo and In Vitro. Int. J. Environ. Res. Public Health 2021, 18, 11374. https:// doi.org/10.3390/ijerph182111374

Academic Editors: Lon Jeffrey Van Winkle and Rebecca Jean Ryznar

Received: 14 September 2021

Accepted: 25 October 2021

Published: 29 October 2021

Publisher's Note: MDPI stays neutral with regard to jurisdictional claims in published maps and institutional affiliations.

Copyright: (c) 2021 by the authors. Licensee MDPI, Basel, Switzerland. This article is an open access article distributed under the terms and conditions of the Creative Commons Attribution (CC BY) license (https:/ / creativecommons.org/licenses/by/ $4.0 /)$.
Abstract: Oocytes and preimplantation embryos require careful regulation of the redox environment for optimal development both in vivo and in vitro. Reactive oxygen species (ROS) are generated throughout development as a result of cellular metabolism and enzyme reactions. ROS production can result in (i) oxidative eustress, where ROS are helpful signalling molecules with beneficial physiological functions and where the redox state of the cell is maintained within homeostatic range by a closely coupled system of antioxidants and antioxidant enzymes, or (ii) oxidative distress, where excess ROS are deleterious and impair normal cellular function. in vitro culture of embryos exacerbates ROS production due to a range of issues including culture-medium composition and laboratory culture conditions. This increase in ROS can be detrimental not only to assisted reproductive success rates but can also result in epigenetic and genetic changes in the embryo, resulting in transgenerational effects. This review examines the effects of oxidative stress in the oocyte and preimplantation embryo in both the in vivo and in vitro environment, identifies mechanisms responsible for oxidative stress in the oocyte/embryo in culture and approaches to reduce these problems, and briefly examines the potential impacts on future generations.

Keywords: redox; ROS; embryo; oocyte; antioxidants; assisted reproductive technology; transgenerational effects

\section{Introduction}

Preimplantation embryo development requires tight regulation of molecular and physiological processes for optimal blastocyst formation, hatching and implantation. One set of mechanisms that need careful balance in these early stages of development is redox control within the oocyte and embryo, and the surrounding maternal environment [1,2]. The redox state of a cell depends on the ratio of oxidised and reduced molecules [3] and redox homeostasis (i.e., oxidative eustress) helps maintain normal cellular function [4-6].

Reactive oxygen species (ROS) are generated by a variety of cellular metabolic activities and, in particular, as a by-product of ATP generation mediated by mitochondrial respiration $[7,8]$. However, either excessive accumulation of ROS or highly reduced conditions upsets redox homeostasis, results in oxidative distress and, in the embryo, acts to impair development by a variety of mechanisms (Figure 1) [1,4-6,9-11]. The sensitivity of the oocyte and preimplantation embryo to oxidative stress also presents challenges for in vitro assisted reproductive technologies (ART), including oocyte maturation, fertilisation, and embryo culture. Redox imbalance during early development can also result in transgenerational effects to the immediate offspring and later generations [12-14].

This review examines the effects of oxidative stress in the oocyte and preimplantation embryo in both the in vivo and in vitro environment, identifies mechanisms responsible for oxidative stress that affect the current oocyte/embryo and effects on future generations, as well as approaches to reduce these problems. 


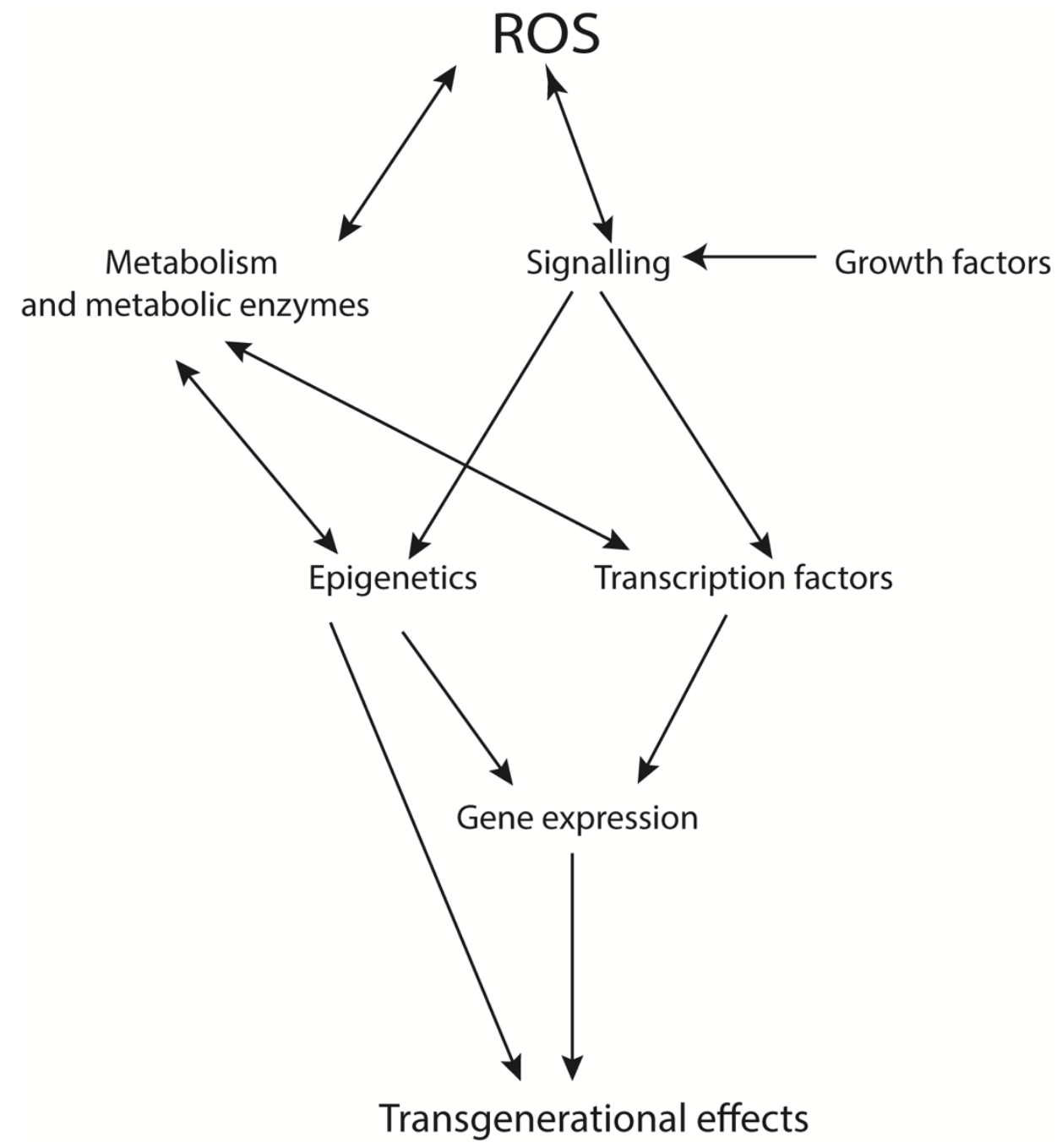

Figure 1. Effects of ROS on cellular function. ROS production has a multitude of impacts on cellular function and can act in both a beneficial and deleterious manner. ROS are produced as a 'by-product' of cellular metabolism and as a result of various cell-signalling pathways, including many activated by growth factors. They can also directly affect the activity of signalling pathway components and metabolic enzymes, leading to changes in cellular metabolic profile and energy usage. In turn, these changes in metabolism and signalling can lead to changes in the epigenetic landscape and the activity of transcription factors, altering gene expression. Since these events directly and indirectly affect the reproductive system, transgenerational effects resulting from normal and aberrant ROS production can and do occur.

\section{Cellular ROS}

ROS is a term used to describe oxygen-containing molecules that are highly reactive and electron-accepting [15]. Due to the fact the 2 lone electrons in the outer-most orbital of molecular oxygen, $\mathrm{O}_{2}$, have the same spin quantum number, it can only accept one electron at a time as it is reduced to $\mathrm{H}_{2} \mathrm{O}$ [8]. This results in the production of a series of intermediates, namely the free-radical superoxide anion $\left(\mathrm{O}_{2} \cdot{ }^{-}\right)$, non-radical hydrogen peroxide $\left(\mathrm{H}_{2} \mathrm{O}_{2}\right)$, and the free-radical hydroxyl ion $(\mathrm{OH} \cdot)$ [8]. (The formation of highly reactive singlet oxygen, ${ }^{1} \mathrm{O}_{2}$, an electronically excited form of $\mathrm{O}_{2}$, and its conversion to the powerful oxidising agent ozone, $\mathrm{O}_{3}$, also occurs in animals. For a review, see Ref. [16]).

ROS production is ubiquitous in cells and, under conditions of oxidative eustress, ROS are now known to play an increasingly large number of roles in normal organismal physiology [5]. However, supraphysiological concentrations of ROS-i.e., the excessive production of ROS that cannot be counteracted by the cell's natural antioxidant systems [17]—results in 
oxidative distress [4]. This oxidative stress can lead to a large variety of cellular-mechanism dysfunctions culminating, for example, in growth arrest and premature cell death [18-21].

\subsection{Sources of Cellular ROS}

ROS are generated in many ways at physiologically relevant rates including:

(i) Directly by enzyme-catalysed reactions. There are over 40 enzymes that generate $\mathrm{O}_{2} \cdot{ }^{-} / \mathrm{H}_{2} \mathrm{O}_{2}$ (see Table 1 [4]) chief among them the NOX family of multi-subunit NADPH oxidases, the transmembrane components of which are responsible for transporting electrons across biological membranes: The oxidation of NADPH (to $\mathrm{NADP}^{+}$and $\mathrm{H}^{+}$) on one side of the membrane results in concerted reduction of $\mathrm{O}_{2}$ to $\mathrm{O}_{2} \cdot{ }^{-}\left(\right.$or $\left.\mathrm{H}_{2} \mathrm{O}_{2}\right)$ on the other [21] (Figure 2).

In addition to NOX, which are found principally in the plasma, nuclear and endoplasmic reticulum (ER) membranes, peroxisomes and lysosomes are major generators of ROS $[18,20]$. ROS are also produced in the plasma membrane following oxidation of arachidonic acid by cyclooxygenase and lipoxygenase [22]. Other sources include ROS production from amino-acid metabolism and the reduction of hypoxanthine to xanthine by xanthine oxidoreductase (XOR), which generates $\mathrm{O}_{2} \cdot{ }^{-}$[23] (Figure 2).

(ii) As a 'by-product' of electron transport chain (ETC) flux. $0.12-2 \%$ of the $\mathrm{O}_{2}$ consumed by a cell in vitro is converted to $\mathrm{O}_{2} \cdot{ }^{-}$in the ETC $[7,8,24-26]$, though the values in vivo are likely to be lower $[8,26]$. ETC-generated $\mathrm{O}_{2} \cdot{ }^{-}$can spontaneously dismutate to $\mathrm{H}_{2} \mathrm{O}_{2}$ but the rate is much slower than in the presence of physiological concentrations of mitochondrial superoxide dismutase (MnSOD) [26,27]. As a result, the concentration of $\mathrm{O}_{2}{ }^{-}$ in mitochondria is as little as $10-200 \mathrm{pM}$ [28], while physiologically relevant concentrations of $\mathrm{H}_{2} \mathrm{O}_{2}$ are maintained in the low nanomolar range (roughly 1-10 nM) [4].

There are at least 11 sites in the ETC where $\mathrm{O}_{2} \cdot{ }^{-} / \mathrm{H}_{2} \mathrm{O}_{2}$ are produced. The principle sites are Complexes I-III where, in certain cellular states, generation can also occur by reverse electron transport [24,26]. Production can also occur via functional and physical interactions of enzymes, such as proline oxidase (POX), with ETC complexes [29]. For example, POX itself, which oxidises proline to pyrroline-5-carboxylate (P5C) doesn't produce ROS but rather directs high-energy electrons into the ETC in the form of $\mathrm{FADH}_{2}$ through its coupling to Complex II [29-32]. Overexpression of POX and/or its increased activity in the presence of proline results in an acute burst of ROS via the ETC [8,26,29,31,33-35].

The balance of generation of ROS from mitochondrial and non-mitochondrial sources will depend on the cell type as well as its metabolic status at the time. In resting mouse skeletal muscle-derived myoblasts, there is roughly equal generation of $\mathrm{H}_{2} \mathrm{O}_{2}$ from each ( $45 \%$ from the ETC and $\sim 40 \%$ from NOX) [36]. 


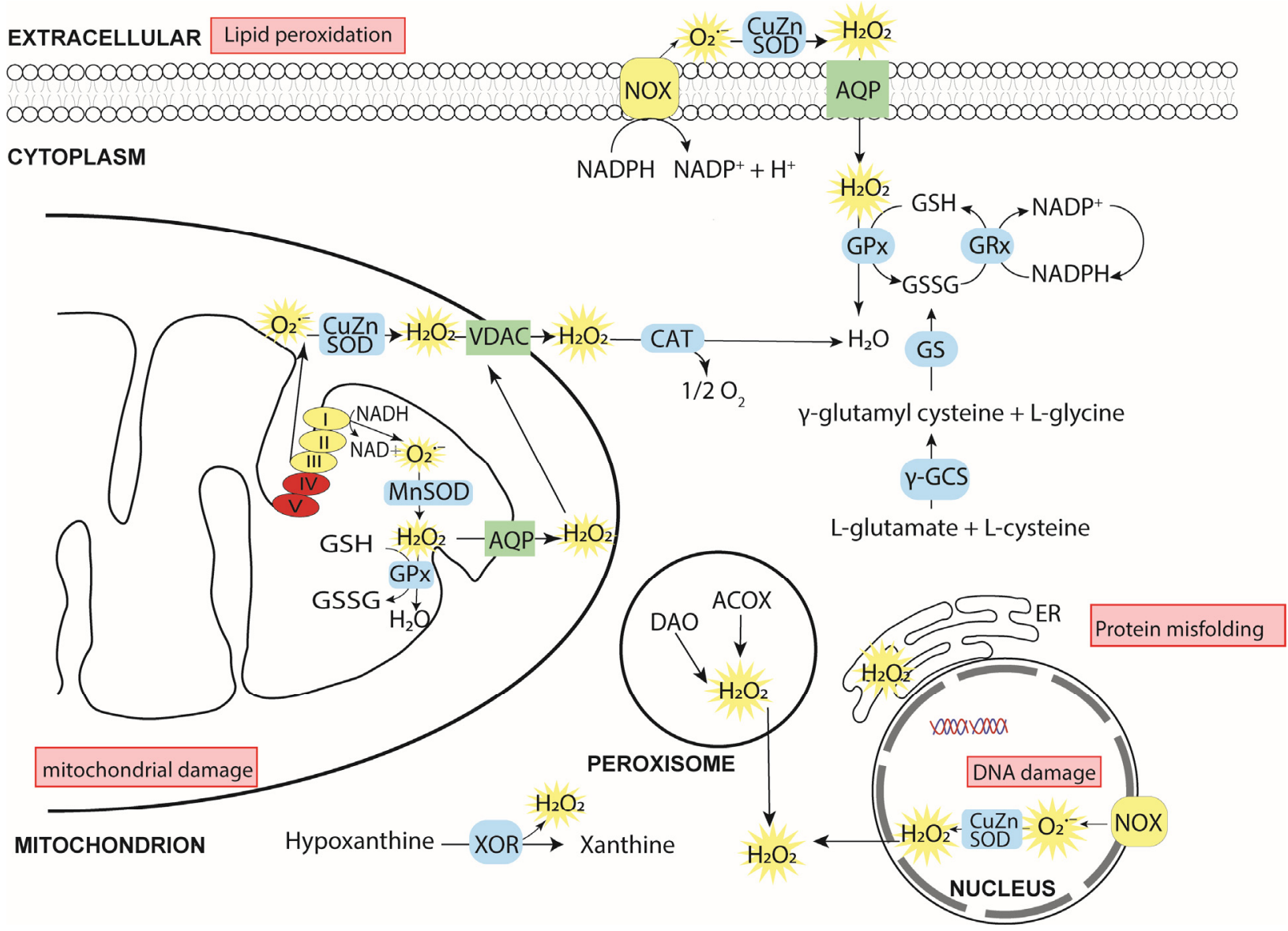

Figure 2. Cellular sources of ROS and antioxidants, and the effects of oxidative distress. Numerous cellular enzymes (yellow discs) produce ROS (shown in yellow sunbursts), whose homeostatic concentrations are controlled by a comprehensive system of antioxidants (only GSH is shown here) and antioxidant enzymes (blue discs) [37]. Principal sources are NOX, Complexes I-III of the mitochondrial electron transport chain due primarily to electron leakage $[8,26]$, and to various enzymes (not shown), such as proline oxidase, which are coupled to Complex II $[8,26]$. The principal ROS signalling molecule is $\mathrm{H}_{2} \mathrm{O}_{2}$ (physiological concentration $\approx 1-10 \mathrm{nM}[8,26]$ ), which can penetrate membranes directly or (more efficiently) by transmembrane transporters (green disks). Oxidative distress occurs when the antioxidant system cannot maintain homeostatic concentrations of ROS, which can lead to a range of cellular dysfunctions (red boxes), frequently resulting in growth arrest and apoptosis. ACOX, acyl coenzyme A oxidase; AQP, aquaporin; CAT, catalase, CuZnSOD, copper-zinc superoxide dismutase; DAO, diamine oxidase; $\gamma$-GCS, $\gamma$-glutamylcysteine synthetase; GPx, glutathione peroxidase; GRx, glutathione reductase; GS, glutathione synthetase; MnSOD, manganese superoxide dismutase; NOX, NADPH oxidase; VDAC, voltage-dependent anion channel; $X O R$, xanthine oxidoreductase.

\subsection{The (Patho)Physiological Roles of ROS}

\subsubsection{Oxidative Eustress}

Although once deemed a toxic by-product of aerobic respiration that cells must remove in order to maintain normal function, the physiological roles of ROS have, more recently, come to the fore $[4,20,38]$. Levels of ROS generated from various enzymes and adventitious production from the ETC are held within homeostatic concentration ranges by a closely coupled system of antioxidants (e.g., glutathione (GSH), thioredoxin (Trx), vitamins $C$ and E) and redox-regulating enzymes (Figure 2) $[37,39,40]$. This close coupling of generation and removal is exploited by cells in variety of ways: (i) Highly reactive ROS (in particular, $\mathrm{H}_{2} \mathrm{O}_{2}$ ) act as second messengers to modulate the activity of a variety of cellular macromolecules, including metabolic and signalling-pathway enzymes and components of cytoskeletal networks [4,41,42]. (ii) Growth factors and other molecules can stimulate signalling which generate ROS to initiate cellular response to environmental cues [43-46]. 
Collectively, ROS control a pleiotropic range of homeostatic cellular responses including aspects of the hypoxic response, stress response, antioxidant response, autophagy and metabolic adaptation $[4,8,26,42]$, all of which are important for normal oocyte maturation and preimplantation embryo development. In particular, metabolic adaptation includes negative feedback by ETC-generated $\mathrm{H}_{2} \mathrm{O}_{2}$ to fine-tune control of mitochondrial respiration, the balance of molecular sources (e.g., fatty acids, amino acids and carbohydrates) that feed into the TCA cycle and ETC, and the balance of ATP production accorded to anaerobic and aerobic metabolism $[4,8,26]$, and these switches occur at critical times in early development.

The most common target of ROS and redox-mediated signalling is reversible thiol oxidation of specific redox-sensitive proteinaceous cysteines, generally to form intra- and inter-protein disulphide bonds [41,42]. Many of these signalling mechanisms and targets play homeostatic roles in early development where changes in $\mathrm{O}_{2}$ tension and bursts of ROS production are frequent (Figure 3). Oxidative distress, however, can occur, especially during in vitro culture of oocytes/embryos where maternal control systems are absent and those of the oocyte/embryo compromised.

These redox-regulated signalling pathways include the NRF2 oxidative stress-response pathway [4]. NRF2 is normally targeted for ubiquitination and proteasomal degradation through its interactions with redox-sensing KEAP1 (the adaptor protein of the Cul3 ubiquitin ligase complex). Oxidant-mediated intermolecular disulphide bond formation between the monomers of the KEAP1 homodimer result in stabilisation of NRF2, which is now free to move to the nucleus and bind antioxidant response elements (AREs). This stimulates expression of a number of genes whose products enzymatically and non-enzymatically reduce the imposed oxidative stress [47].

Analogously, hypoxia-inducible factors (HIF- $1 \alpha$, HIF- $2 \alpha$ and HIF- $3 \alpha$ ) are key transcription factors regulating cellular responses under hypoxic conditions. HIF- $\alpha$ is normally rapidly degraded under high $\mathrm{O}_{2}$ tension through hydroxylation of key prolines by the oxidant- and oxygen-sensitive HIF prolyl hydroxylases [48,49]. This targets HIF- $\alpha$ for ubiquitination and subsequent proteasomal degradation. On the other hand, decreased prolyl hydroxylase activity promotes HIF- $\alpha$ stabilisation, movement to the nucleus, binding to hypoxia response elements (HREs), and the upregulation of expression of more than 70 genes, including redox-regulating enzymes, and those which help switch energy demand towards glucose metabolism and away from oxidative phosphorylation [50].

The energy switch away from mitochondria and $\mathrm{O}_{2}$ usage under hypoxic conditions can result in the generation of ROS due to the leakage of electrons from the ETC [26]. In a complex interplay, expression of the redox modulator enzyme, Ref-1, is unregulated in the presence of $\mathrm{H}_{2} \mathrm{O}_{2}$. Ref- 1 then stimulates gene expression of HIF- $1 \alpha$, which in turn upregulates the expression of HIF prolyl hydroxylases resulting in negative feedback control of HIF- $1 \alpha$ activity, even while $\mathrm{H}_{2} \mathrm{O}_{2}$ induces disulphide bond-mediated dimerisation and inactivation of the HIF prolyl hydroxylases [48]. Ref- 1 can also reduce disulphide bonds in a number of transcription factors, including HIF- $1 \alpha$, the presence of which generally suppresses their transcriptional activity [51]. The complexity of these homeostatic and interconnected redox-dependent mechanisms, which have been elucidated to some extent in various cellular systems, have been much less explored in oocyte/embryo systems where, nevertheless, $\mathrm{O}_{2}$ tension and $\mathrm{ROS}$ are known to play major roles.

The FoxO class of transcription factors is a target of redox-mediated signalling and, in turn, a mediator of response to ROS: Growth factor- and signalling-mediated increases in ROS lead to phosphorylation of specific FoxO serines and threonines and result in increased expression of genes whose protein products are responsible for redox regulation, including MnSOD, PRx3 and 5, GPx1, mitochondrial thioredoxin, mitochondrial thioredoxin reductase and catalase. In addition, $\mathrm{H}_{2} \mathrm{O}_{2}$-mediated FoxO activation occurs under conditions of nutrient deprivation and results in upregulation of expression of other key genes including those for autophagy [43-45]. 


\subsubsection{Oxidative Distress}

Whilst oxidative eustress represents the cellular responses to homeostatic levels of ROS, excessive levels of ROS result in oxidative distress and a range of cellular pathologies, often resulting in growth arrest and apoptosis [4]. In contrast, increased ROS are also associated with a downregulation of tumour suppressor genes and an increase in prosurvival pathways [52,53]. Aberrant upregulation of expression of NADPH oxidase genes can result in various pathologies [54] including those linked to cancer, diabetes, and a number of inflammatory disorders [20,53]. Dysregulation of redox status during oxidative stress can contribute to the formation of metabolic diseases, hinder cellular metabolism, and block cellular antioxidant defence mechanisms [20,55,56].

ROS and $\mathrm{Ca}^{2+}$ signalling are interlinked. $\mathrm{Ca}^{2+}$ is mainly stored within cells in the ER and release of $\mathrm{Ca}^{2+}$ into the cytoplasm is involved in numerous cellular functions. $\mathrm{Ca}^{2+}$ release is also directly coupled to $\mathrm{Ca}^{2+}$ levels within the mitochondria, due to physical and functional coupling of $\mathrm{Ca}^{2+}$ channels in the ER and mitochondria (e.g., IP3R and VDAC, respectively) [57]. An increase in cytosolic $\mathrm{Ca}^{2+}$ due to release through IP3R causes an increase in mitochondrial $\mathrm{Ca}^{2+}$ which activates oxidative phosphorylation and thus ROS production. $\mathrm{Ca}^{2+}$ also activates MnSOD, which helps abate excessive ROS accumulation and maintain ROS homeostasis. Nevertheless, sustained elevation of cytosolic $\mathrm{Ca}^{2+}$ due to ROS-induced ER stress can disturb the transfer of $\mathrm{Ca}^{2+}$ from ER to mitochondria and cause aberrant mitochondrial metabolism and apoptosis [58]. In addition, oxidative distress causes post-translational modifications of proteins responsible for $\mathrm{Ca}^{2+}$ signalling [58]. For example, thiol oxidants and ROS can inhibit functioning of the sarcoplasmic reticulum $\mathrm{Ca}^{2+}$-transport ATPase (SERCA), preventing uptake of $\mathrm{Ca}^{2+}$ into the ER and restoration of resting cytosolic $\mathrm{Ca}^{2+}$ levels [59].

ROS and glucose metabolism are also linked: Skeletal muscle cells exposed to exogenous $\mathrm{H}_{2} \mathrm{O}_{2}$ have increased glucose uptake [60], and the expression of the glucose transporter, GLUT1, is upregulated in L6 muscle cells when exposed to continuous exogenous ROS-generating systems (xanthine/xanthine oxidase and glucose/glucose oxidase) [61].

\section{The Effect of Oxidative Eustress and Distress on Oocyte Maturation, Fertilisation, and Embryo Development}

Oocyte maturation, fertilisation and embryo development in the reproductive system take place in a highly complex milieu of factors from the mother and the oocyte/embryo itself. During folliculogenesis there is a steady decline in $\mathrm{O}_{2}$ tension in the follicular fluid $[62,63]$ and around the time of ovulation there is a decrease in blood flow to the ovary, thus subjecting the oocyte to decreasing $\mathrm{O}_{2}$ tension from the primary follicle stage to the point of ovulation [62-64]. There is also a decrease in $\mathrm{O}_{2}$ tension from the top of the oviduct $(\sim 8 \%)$, where fertilisation takes place, to the uterus $(\sim 2 \%)$, at the time of blastocyst formation and implantation [63,65] (Figure 3). ROS are generated under these conditions, sometimes in acute bursts required for developmental progression but, overall, ROS concentrations are normally maintained within their homeostatic ranges by the maternal environment $[11,66,67]$, the maturing and ovulated oocyte, and pre-implantation embryo [11,66,68-71].

In stark contrast, culture media for oocyte maturation, fertilisation, and embryo development are extremely simple, consisting of little more than buffers, basic salts, and energy sources (generally a combination of lactate, pyruvate and glucose) [72-74]. The inclusion of HEPES buffer in culture media, such as those used for fertilisation, drives production of $\mathrm{O}_{2}{ }^{-}$and, subsequently, production of $\mathrm{H}_{2} \mathrm{O}_{2}$ [75]. Many culture media also contain serum as a protein source for embryo development and/or serum albumin, which reduces adhesion of embryos to surfaces and promotes hatching [76,77]. However, both are a source of ROS generation $[11,75,78]$. These differences between the in vivo and in vitro situations present many challenges for assisted reproduction. Some of these challenges and solutions are explored below. 


\begin{tabular}{|l|l|}
\hline \multicolumn{2}{|c|}{ Cleavage } \\
\hline Oxidative stressors & $\begin{array}{l}\text { Antioxidants and } \\
\text { redox enzymes }\end{array}$ \\
\hline Initial division [110] & GCS [66] \\
G 2 phase of the & GPx [66] \\
second cell cycle [71] & MnSOD [66] \\
8-cell to compaction & CuZnSOD [66] \\
increase [66] & Glutathione [66] \\
& Amino acids [161] \\
& Polyamines [177] \\
\hline
\end{tabular}

8\% Oxygen tension

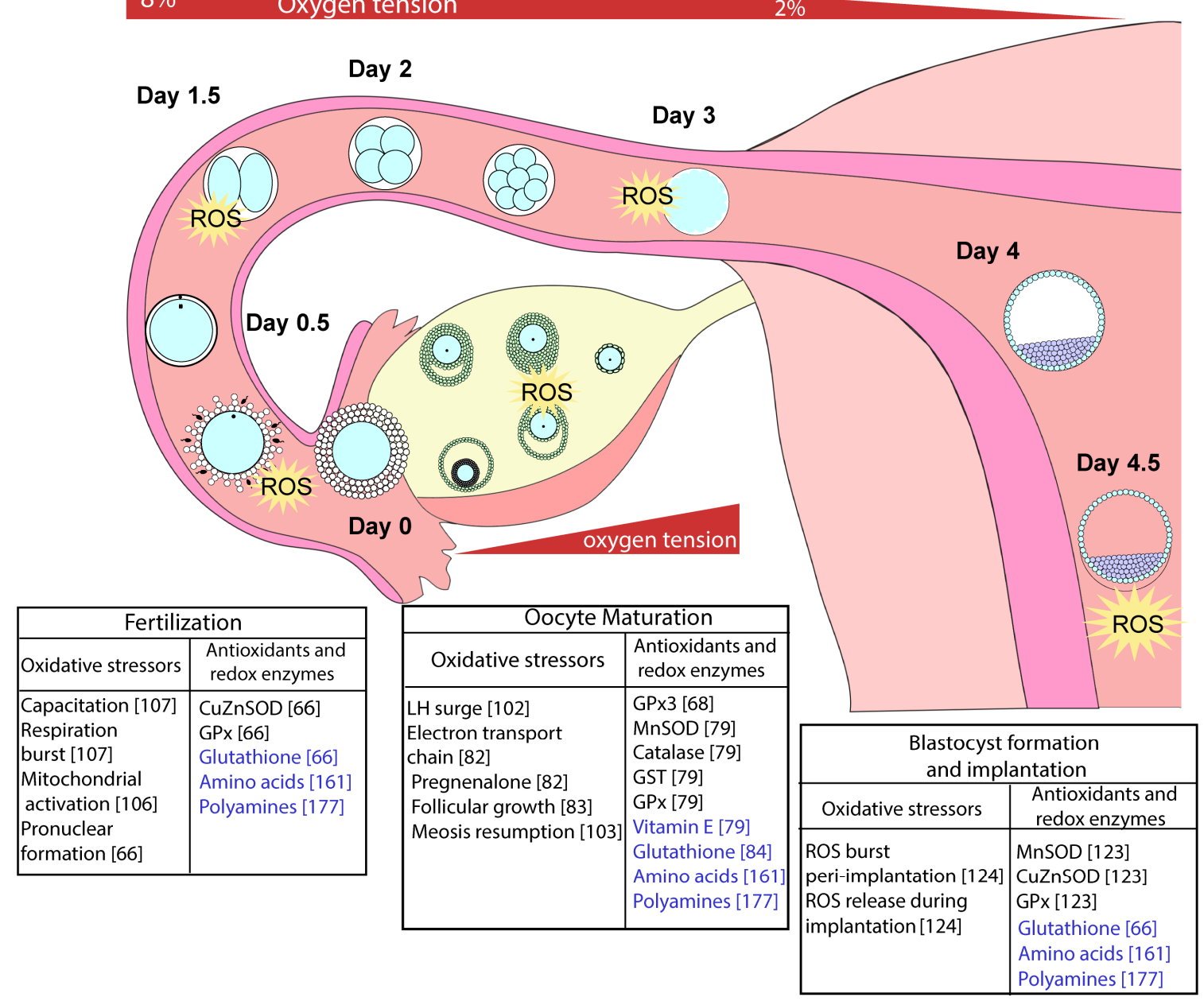

Figure 3. Sources of ROS and antioxidants during in vivo embryo development. The preimplantation embryo develops over 5 days in the mouse in vivo. The maternal reproductive tract is an environment low in oxygen, with an oxygen gradient of approximately $8 \%$ to $2 \%$ from the oviduct to the uterus. This, along with a number of antioxidants and antioxidant enzymes, supports redox homeostasis and helps prevent irreversible oxidative damage. During oocyte maturation and preimplantation embryo development, there are numerous oxidative stressors including at ovulation, fertilisation, cellular division, and hatching. Some examples of the control of the action of these stressors by redox enzymes (in black) and antioxidants (in blue) are shown. References are shown in square brackets.

\subsection{Oocyte Maturation and Fertilisation}

The follicular fluid in which oocytes are bathed is rich in antioxidants (including vitamin $\mathrm{E}$ ( $\alpha$-tocopherol), $\beta$-carotene and GSH) and redox-controlling enzymes (including glutathione peroxidase (GPx) 3, superoxide dismutases (CuZnSOD, MnSOD, SOD3), catalase, glutathione $S$-transferase (GST), and glutathione reductase (GRx) $[67,79]$. In addition, cumulus cells provide the oocyte with GSH, as well as cysteine and NADPH for generation 
of GSH, via gap junctions connecting the cells in the follicle $[70,80]$. This well-balanced redox system maintains homeostatic levels of ROS and an appropriate environment for folliculogenesis and oocyte maturation $[67,69,79,81-83]$. Excess ROS in the follicular fluid results in damage to oocytes, including to the genome and lipid membranes [84]. In addition, the composition of follicular fluid is dynamic during folliculogenesis: As follicles increase in size, total antioxidant capacity (TAC) (a measure of the amount of ROS scavenged by a sample [85]) increases and $\mathrm{H}_{2} \mathrm{O}_{2}$ decreases [84]. The increase in TAC appears to be required to combat what would otherwise be a rising concentration of $\mathrm{H}_{2} \mathrm{O}_{2}$ [84].

There's a close correlation between ROS in the follicular fluid on the one hand and oocyte grade on the other [86-88]: Follicles for which the follicular fluid has an average ROS level $<\sim 70 \mathrm{cps} / 400 \mu \mathrm{L}$ produce grade III oocytes, which fertilise and produce grade I and II 4-cell embryos, whereas follicles for which this average is $>\sim 85 \mathrm{cps} / 400 \mu \mathrm{L}$ produce less mature (grade I and II) oocytes, which generally don't fertilise and, when they do, produce lower quality (grade III and IV) embryos [88]. An upper control limit of 107 cps / $400 \mu \mathrm{L}$ significantly distinguishes the fertilisation percentage, embryo quality, and the extent of embryo DNA fragmentation regardless of the cause of infertility (surgically removed fallopian tubes, endometriosis or polycystic ovary syndrome) [88], suggesting that high ROS levels represent a generalised cause of failure for in vitro fertilisation (IVF) regardless of the underlying physiology. Consistent with this, follicles from IVF patients that have a greater percentage of ROS-producing granulosa cells (77\% compared to $61 \%$ ) are less likely to contain an oocyte [87]. Similarly, blastocysts generated from oocytes where the percentage of ROS-producing granulosa cells are high (70\%) do not implant, whereas blastocysts generated from oocytes with only $40 \%$ ROS-producing granulosa cells do implant [87].

Whole-body irradiation of female mice in the pre-ovulatory stage results in a 6-fold increase in chromosomal abnormalities in the metaphase plate of fertilised embryos, which can be partially overcome by intraperitoneal injection of vitamin $\mathrm{E}$ prior to irradiation [89].

The use of cryopreserved gametes presents challenges for ART. Cryopreserved spermatozoa have decreased antioxidant capacity, which leads to increased ROS in embryos [90,91]. Cryopreservation of oocytes subjects them to oxidative stress and makes them more susceptible to oxidative damage [92-94] and increased risk of failure of IVF and intracytoplasmic sperm injection (ICSI) [93,95]. Embryos derived from vitrified oocytes have $>1000$ differentially expressed genes at the 2-cell stage compared to embryos generated from fresh oocytes. Some of the genes whose expression is altered are related to redox pathways. For example, GPx6 expression is increased, possibly as a compensatory mechanism to protect against the effects of oxidative stress that occurred during oocyte vitrification [92]. Prolonged incubation of spermatozoa and oocytes during IVF also leads to increased environmental ROS due to its release from immature or dead spermatozoa. To some extent, this can be combatted by decreasing incubation time during fertilisation [96].

During in vivo maturation, oocytes are subjected to decreasing $\mathrm{O}_{2}$ tension (Figure 3). Despite this, increases in $\mathrm{O}_{2}$ consumption and ROS levels are required at critical times to promote further development. For example, $\mathrm{O}_{2}$ consumption increases in oocytes as ovulation approaches, coinciding with a switch in energy source from pyruvate to glucose $[97,98]$. In addition, an increase in the level of $\mathrm{H}_{2} \mathrm{O}_{2}$ (from 66 to $77 \mathrm{ng} \mathrm{H}_{2} \mathrm{O}_{2}$ / oocyte) is required for the resumption of meiosis in rat oocytes from the diplotene to MI stage [83]. The burst in $\mathrm{H}_{2} \mathrm{O}_{2}$ modulates signalling by reducing cyclic nucleotide concentrations (cAMP and cGMP) resulting in phosphorylation of CDK1 (at Thr14/15), which in turn destabilises maturation-promoting factor to allow completion of meiosis II [99,100].

Intra-oocyte defence mechanisms during meiotic maturation are important for protecting DNA from oxidative damage. For example, catalase is localised to the nucleus at the germinal vesicle stage and in the peri-chromosomal region following breakdown of the nuclear envelope and thereby protects the DNA from ROS-related damage [101]. The LH surge, which triggers the final stages of oocyte meiotic maturation, induces an increase in ROS, which is required for EGF receptor-mediated signalling events that are essential for 
maturation. Thus, exogenous antioxidants, such as N-acetylcysteine (NAC) or butylated hydroxyanisole (BHA) prevent LH-induced activation (by phosphorylation) of the EGF receptor and its downstream effector p42/44 MAPK [102]. Similarly, if ROS is reduced in vitro using scavengers such as 2(3)-tert-butyl-4-hydroxyanisole or nordihydroguaiaretic acid (NDGA), oocyte maturation is also inhibited $[83,103]$. On the other hand, oocytes with $\mathrm{H}_{2} \mathrm{O}_{2}$ over $90 \mathrm{ng} /$ oocyte undergo apoptosis [83]. These results show that while bursts in ROS are critical for developmental progression, they must still be carefully controlled.

The redox state of oocytes is further altered during fertilisation, with a peak in both $\mathrm{O}_{2}$ consumption and ROS [104]. The burst in $\mathrm{O}_{2} \cdot{ }^{-}$resulting from increased NADPH oxidase and mitochondrial activity in bovine sperm results in redox-induced efflux of cholesterol from the sperm plasma membrane, and a large global increase in tyrosine phosphorylation driven by cAMP/PKA signalling [105-109]. Furthermore, serum or serum albumin promotes a burst of ROS that triggers capacitation (and subsequent fertilising ability) of sperm at the early, intermediate and late stages through activation of an interconnected panoply of signalling pathways including PKA and ERK, and this can be inhibited by incubation of sperm with antioxidant enzymes such SOD and catalase [78].

Similarly, ROS production in sperm-activated bovine oocytes peaks during sperm penetration/sperm-head decondensation, with subsequent peaks at the initiation of pronuclear formation and at the time of the first mitotic division [110]. Again, these bursts in ROS are normally kept under appropriate homeostatic control by the antioxidant defence mechanisms of the oviductal fluid, which includes maternal upregulation of the expression of CuZnSOD and GPx [11,66,111].

Increased ROS commonly leads to male infertility, with high ROS levels causing DNA damage and reducing fertilisation in vivo and in IVF [112-114]. During ICSI, using sperm with high levels of ROS can still result in successful fertilisation but embryo quality is compromised and the percentage of live births reduced, presumably in part as a result of increased sperm DNA damage [115]. The problem is exacerbated as a result of ROScontaining medium being injected into the oocyte along with the sperm [116].

Female reproductive ageing is tightly linked to a decrease in ovarian antioxidant enzymes and hence an increase in oxidative stress. Granulosa cells in older IVF patients have reduced expression of CuZnSOD, MnSOD and catalase, and morphologically defective mitochondria and ER $[117,118]$. Aged oocytes show abnormalities in the structure of organelles, consistent with the effects of oxidative stress, including dilated smooth ER and Golgi apparatus, and abnormal mitochondria [118]. Increased oxidative stress during reproductive ageing results in damage to DNA and organelles leading to increased aneuploidy in the oocyte [119-121]

\subsection{The Preimplantation Embryo}

ROS levels remain relatively constant during the cleavage stages of in vivo pre-implantation development (i.e., 2-cell to 8-cell stages in the mouse) [71] and, following compaction, the embryo increasingly relies on the use of glucose over pyruvate, which may be required to support the proliferative burst and differentiation that begins at this time [122,123].

Peri-implantation blastocysts produce a burst of $\mathrm{O}_{2}{ }^{-}$and decrease levels of SOD compared to pre- and post-implantation embryos [124]. In vitro, the addition of $\mathrm{O}_{2}{ }^{-}$ around the time of hatching results in thinning of the zona pellucida, suggesting that the burst of ROS production for in vivo blastocysts assists in hatching. Furthermore, a range of $\mathrm{O}_{2} \cdot{ }^{-}$scavengers used on both in vitro and in vivo blastocysts reduces hatching [124].

Excessive accumulation of ROS, however, at various times in the life of the preimplantation embryo compromises development, and many problems have been identified that contribute to this in the in vitro environment (Figure 4) $[125,126]$. Among these are: (i) The simplicity of culture media, including especially their generally poor antioxidant properties. (ii) Culture in, or even brief exposure to, $21 \% \mathrm{O}_{2}$, which results in generation of excess ROS. (iii) Laboratory light, which stimulates ROS production. 
Various strategies have been used to overcome, or at least identify, these problems. For example, TAC assays [85] can be used to quantify the embryo's ability to cope with oxidative stress. In human IVF cycles, embryos with a higher TAC as measured in culture medium on day 1 had improved fertilisation and cleavage rates, improved development to the blastocyst stage, and less embryonic fragmentation on day 3 of development than those with a lower TAC [125]. in vitro cultured embryos have higher levels of aneuploidy than their in vivo counterparts and the increased oxidative stress in the laboratory is a contributing factor to this, including culture media components, $\mathrm{pH}$, osmolality, laboratory light and $\mathrm{O}_{2}$ concentration [126,127].

The maternal reproductive tract provides support for the developing embryo and, consistent with this, co-culture of mouse embryos in vitro with human oviductal epithelial cells improves development: 75, 60, and 40\% embryos develop to the 4-8 cell, blastocyst stage and hatching stage, respectively, compared to 20,3 , and $0 \%$ in contactless coculture or without coculture [128]. Coculture eliminates the build-up of $\mathrm{O}_{2}{ }^{-}$in the medium [128]. In a related study, maternal expression of oviductal microsomal epoxide hydrolase (Ephx1), an enzyme important in detoxifying genotoxic molecules, is upregulated in the oviduct over the first 5 days of mouse embryo development [129]. In addition, inhibition of human EPHX1 by cyclohexene oxide or 1,1,1-trichloropropene-2,3-oxide in human oviductal cells cocultured with mouse embryos increases ROS and prevents the beneficial effect of coculture on blastocyst formation and hatching [129].

Knockout of very few redox-regulating/antioxidant genes pose issues for preimplantation development [23] presumably, in part, due to mechanistic redundancy. However, mouse embryos knocked out for Trx1, the gene for the small antioxidant protein Trx, are embryonic lethal at $\sim$ E3.5 [130] and knockout of the redox-modulating enzyme, Ref-1 [48,51], is embryonic lethal shortly after implantation [131]. Knockout/knockdown of some redoxsensing/regulating transcription factors can also disrupt development at an early stage. Knockdown of FoxO proteins (FoxO1, FoxO3 and FoxO4) in mice impairs preimplantation embryo development [132]: The majority of the FoxO knockdown embryos arrest at the 2 -cell stage, and blastocyst formation decreases from $\sim 70 \%$ to $\sim 25 \%$. ROS in these embryos is elevated 3-4 fold, and in the 2-cell arrested embryos there are 1.5-3 fold increases in Fasl and cleaved caspase 3 (responsible for apoptosis) and p53 and p21 (responsible for cell-cycle arrest) [132].

\subsubsection{Use of Antioxidants for In Vitro Culture}

In embryo culture media, usually the only antioxidant included is a chelator, such as EDTA, which sequesters redox catalysts such as heavy metal ions. In particular, $\mathrm{H}_{2} \mathrm{O}_{2}$ and $\mathrm{O}_{2} \cdot{ }^{-}$can react in the $\mathrm{Fe}^{2+} / \mathrm{Fe}^{3+}$ Haber-Weiss catalytic cycle to form the highly reactive $\mathrm{OH} \cdot[11,133]$, which in many species is responsible for preimplantation block $[71,134,135]$. In mouse, the addition of EDTA to culture medium overcomes the 2-cell block (which occurs at the G2 phase of the cell cycle) predominantly by acting as a chelator $[134,136]$. Consistent with this, a 30-min exposure of mouse embryos in vitro to exogenously added $\mathrm{H}_{2} \mathrm{O}_{2}(50 \mu \mathrm{M})$ reduces the percentage that pass the block from $>70 \%$ to $40 \%[137,138]$, while addition of the reducing agent $\mathrm{N}$-acetyl-L-cysteine along with $\mathrm{H}_{2} \mathrm{O}_{2}$ completely overcomes this $[137,138]$.

The addition of GSH to mouse embryo culture medium reduces ROS in these embryos and increases the percentage of blastocysts [139]. Similar results were obtained in the porcine [140] and bovine systems [141]. Consistent with the importance of GSH, knockout mice for GPx4 [142], $\gamma$-glutamylcysteine ligase [143] or glutathione synthetase [144], all of which are required for the formation of GSH, are embryonic lethal.

Melatonin, a tryptophan-derived hormone secreted from the pineal gland to regulate circadian rhythm, is also an antioxidant that scavenges a number of ROS, including OH. and $\mathrm{H}_{2} \mathrm{O}_{2}$, and also upregulates the expression of GPx, catalase, SODs and glutathione reductase [145]. Melatonin improves viability of heat-stressed bovine embryos in culture [146]. Oocyte retrievals in women treated with melatonin had, on average, double the fertilisation 
rate compared to previous cycles, while simultaneously having a one-third reduction in the concentration of intrafollicular concentration of 8-hydroxy-2'-deoxyguanosine (8-OHdG), a biomarker of oxidative stress $[89,147,148]$. The inclusion of melatonin in culture medium for embryo development reduces cleavage times, improves development to the blastocyst stage, and decreases ROS in vitrified embryos [94,149].

Similarly, vitamin C (ascorbic acid) and vitamin E scavenge ROS, and culture medium for porcine embryos supplemented with vitamins $C$ or $E$ reduces the toxic effects of culture under $21 \% \mathrm{O}_{2}$, increases blastocyst cell numbers, and the percentage of embryos that develop to the blastocyst stage, though there is a complex dependence on concentration of the antioxidants and supplementation timing $[150,151]$. The addition of vitamin $C$ to culture medium enables embryos to develop to the blastocyst stage even when they are exposed to oxidative stress by incubating them with PMA-activated leukocyte supernatant [152].

In addition to oxidative stress linked to mitochondria and the cytosol, significant effects can also occur in the ER. ROS accumulation in the embryo can activate the unfolded protein response (UPR) pathways leading to accumulation of unfolded or misfolded proteins in the ER, apoptosis, changes in gene expression, and developmental errors [153,154]. Mouse embryos cultured in the presence of $2 \%$ DMSO, which causes oxidative stress, have increased mitochondrial $\mathrm{Ca}^{2+}$, resulting in mitochondrial-dependent apoptosis [155]. In addition, the morula cultured in 2\% DMSO upregulate expression of ER stress genes GRP78/BIP and UPR genes including Hspa5, Hsp90b1, Ddit3, and Atf4 which contribute to the increased apoptosis and developmental arrest at the 2-cell, 4-cell, and morula stages in a dose-dependent manner [155]. Reducing ER stress in cultured bovine embryos using the bile-acid tauroursodeoxycholate decreases ROS and increases the percentage of embryos that reach the blastocyst stage [156].

A large number of other antioxidants from a variety of sources have been used to promote oocyte and embryo development in vitro, generally with similar success, although determination of the appropriate concentration range for beneficial effect is an issue [146,157-160].

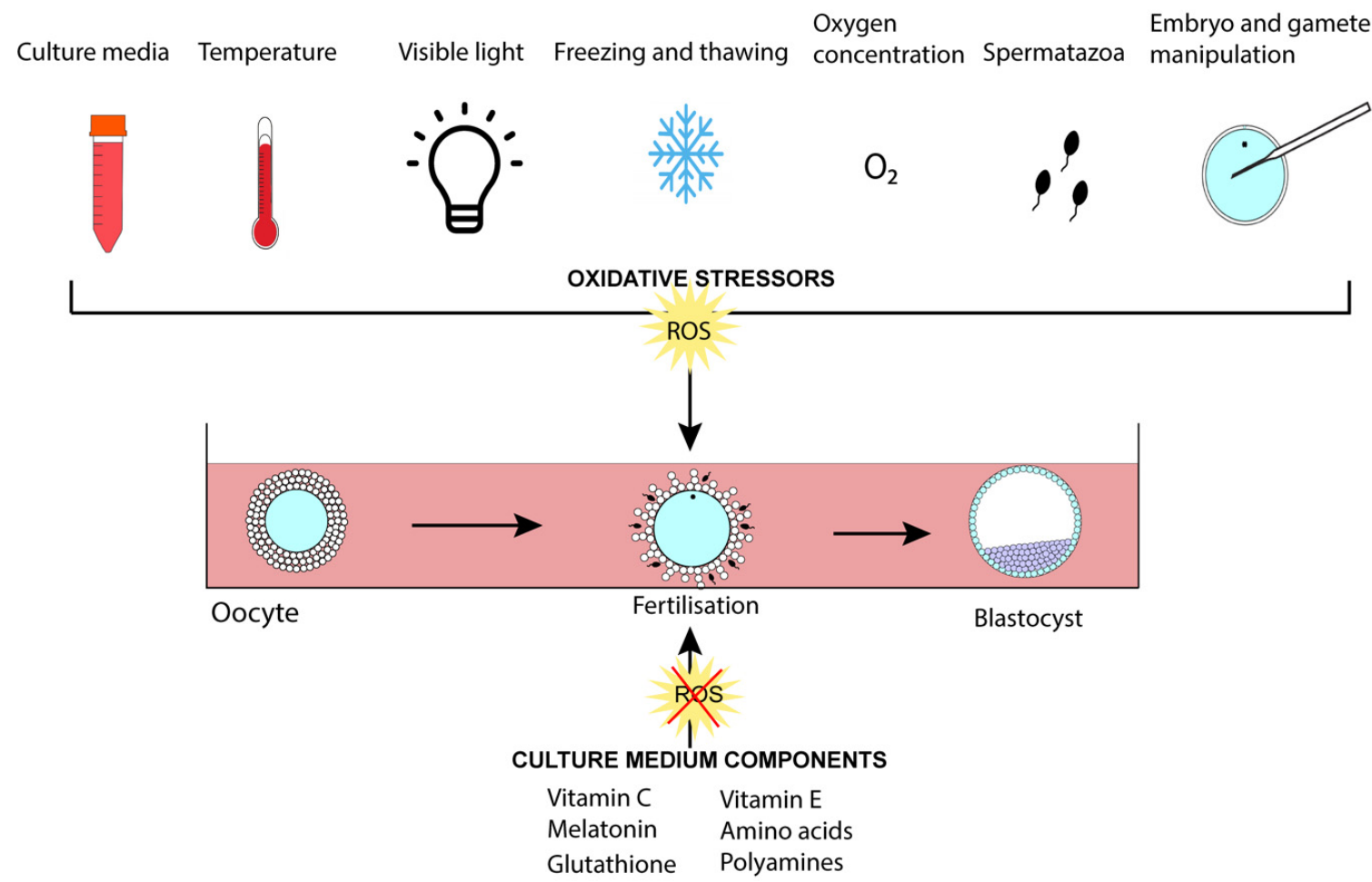

Figure 4. Sources of ROS for in vitro cultured oocytes and embryos. Oxidative stress can be induced by a number of laboratory processes, as shown, and a number of antioxidants can be added to the culture medium to combat these excessive ROS levels. 


\subsubsection{Amino Acids and Polyamines}

The addition of individual and combinations of proteinogenic and other amino acids to culture media is also commonly used due to the presence of amino acids in the oviductal and uterine fluids [161-164]. Of these, proline and its close analog pipecolic acid can reduce ROS by a number of possible mechanisms, including: (i) Direct scavenging by the secondary amine of the ring structure $[32,165,166]$. (ii) Metabolism to glutamate, a precursor for GSH production $[35,167,168]$. (iii) Suppression of ETC activity (a major cellular source of ROS) $[29,169,170]$. In this last case, the suppression by proline involves POX, the enzyme that converts proline to P5C [33,34]. While this initially results in acute generation of ROS (due to the physical coupling of POX to Complex II) [29], the long-term effect is downregulation of the expression of ETC genes, and hence the activity of the ETC [29].

Proline acts as a cryoprotectant for oocytes [93] and sperm [171] in part by acting as a ROS scavenger, which reduces the damage associated with oxidative stress. Proline added to the storage medium for boar sperm also results in increased GSH, and catalase and SOD activity. Upon thawing, sperm parameters improve, including those for motility and acrosome integrity. Oxidative stress upon exposure of thawed semen to $\mathrm{H}_{2} \mathrm{O}_{2}$ is also reduced in the presence of L-proline [171].

The addition of proline or pipecolic acid only during fertilisation reduces mitochondrial activity by $40 \%$ and ROS levels by $60 \%$, and improves later development to the blastocyst stage and hatching [162], consistent with the idea that a metabolically 'quiet' oocyte has better developmental potential. Similarly, proline added during embryo culture also improves development to the blastocyst stage [163]. In the porcine trophectoderm cell line, $\mathrm{pTr}$, proline reduces ROS, the mRNA expressions of glutamate-cysteine ligase catalytic subunit and glutathione synthetase increases, as do GSH levels [169]. Selected other amino acids can sometimes substitute for proline: For example, glutamine and hypotaurine reduce $\mathrm{H}_{2} \mathrm{O}_{2}$ levels in porcine embryos, improve blastocyst development and blastocyst cell numbers, and reduce DNA damage [172]. Though the molecular mechanisms are unclear, those for glutamine (a precursor for glutathione) don't appear to be glutathione dependent, and it's notable that the antioxidant, hypotaurine, can't be synthesised by oocytes/embryos and therefore would normally be supplied from maternal sources [172,173].

However, the effects of amino-acid supplementation of oocyte/embryo culture medium are not easily predictable: While some amino acids are beneficial to maturation/development, other amino acids inhibit their beneficial effects (e.g., by competing for uptake via amino-acid transporters), or are themselves toxic [162,163,174,175]. For example, supplementation of IVF culture medium with glycine, cysteine and glutamate, the three amino acids required for producing GSH, reduce development of bovine embryos [174].

Polyamines, such as spermine and spermidine, can scavenge $\mathrm{H}_{2} \mathrm{O}_{2}$-generated $\mathrm{OH}$, via the Fenton reaction, as well as ${ }^{1} \mathrm{O}_{2}$ [176] and are essential components of seminal fluid and the female reproductive tract; their absence resulting in male infertility and failed embryogenesis [177]. The addition of $25 \mu \mathrm{M}$ spermine or spermidine to culture medium containing high glucose, a condition that induces oxidative stress, reduces lipoperoxidation in midgestation rat embryos and reverses developmental defects [178]. Spermine (10-500 $\mu \mathrm{M})$ increases GSH concentrations and decreases ROS in in vitro matured porcine oocytes and increases the percentage of blastocysts following parthenogenetic activation [179]. Given that proline can be a major source for the production of polyamines [177,180,181], these data are suggestive of an additional role of this amino acid in developmental processes. Consistent with this, the porcine placenta produces polyamines using proline as the major amino-acid source [181].

\subsection{3. $\mathrm{O}_{2}$ Tension and Oxidative Stress}

$21 \% \mathrm{O}_{2}$ imposes oxidative stress on embryos, as measured by ROS accumulation and its effects, as well as triggering mechanisms which attempt to reduce the stress. For example, bovine embryos cultured at $21 \% \mathrm{O}_{2}$ have fewer inner cell mass (ICM) and 
trophectoderm (TE) cells than those cultured at $5 \% \mathrm{O}_{2}$, despite upregulation of expression of oxidant-reducing pathways, such as the NRF2 pathway, and a range of antioxidant enzymes [182,183].

In vitro culture of embryos alters mitochondrial structure, with $\mathrm{O}_{2}$ tension affecting the extent of this change [184]. Blastocysts developed in $21 \% \mathrm{O}_{2}$ have more abnormal mitochondria, with more mitochondrial vacuoles and less mitochondrial DNA, compared to blastocysts flushed from the uterus [184]. These problems are reduced in 5\% $\mathrm{O}_{2}$ [184]. Similarly, mitochondrial activity in bovine blastocysts improves if $\mathrm{O}_{2}$ tension is reduced from $21 \%$ to $5 \%$ [183]. Consistent with this, addition of $30 \mu \mathrm{M} \mathrm{H}_{2} \mathrm{O}_{2}$ to culture medium of mouse zygotes to induce oxidative stress reduces mitochondrial membrane potential, and mitochondrial activity declines by $40 \%$ [185].

Compared to bovine embryos cultured in $5 \% \mathrm{O}_{2}$, those cultured in $21 \% \mathrm{O}_{2}$ have increased ROS production. $21 \% \mathrm{O}_{2}$ activates the NRF2 redox-sensitive stress-response pathway from the 8-cell stage through to the blastocyst stage: The expression of NRF2 increases 2-4 fold at these stages while that of the NRF2 inhibitor, KEAP1, halves [183]. Consistent with this, the expression of several NRF2-responsive antioxidant genes such as SOD1 (CuZnSOD) and PRDX1 increase. Nuclear localisation of NRF2 also increases in blastocysts formed at day 7 , consistent with its role as a transcription factor binding to chromosomal antioxidant response elements [183].

High $\mathrm{O}_{2}$ tension and oxidative stress in cultured embryos can reduce developmental potential, result in DNA fragmentation, modifies DNA methylation patterns and histones, and the expression of redox-sensitive genes [182,186]. For example, bovine oocyte culture in $21 \% \mathrm{O}_{2}$ leads to downregulation of expression of PAF1 and REST which are important in chromatin organisation and histone modifications as well as for maintaining a state of pluripotency [182]. Oxidative stress also leads to an upregulation of SOX2 and HP1, both of which are involved in changes to DNA methylation and chromatin remodelling [182]. These changes indicate that oxidative stress can alter the epigenetic landscape and interfere with embryo development [187].

Similarly, there are a large number of gene expression changes ( $\geq 2$-fold) between embryos cultured in $21 \% \mathrm{O}_{2}$ compared to those cultured at $2-5 \% \mathrm{O}_{2}[188,189]$. These include genes involved in numerous critical pathways, including biosynthesis, mitochondrial activity, kinase activity, and the microtubule-based cytoskeleton [189].

Since culture in $21 \% \mathrm{O}_{2}$ can induce oxidative stress [190,191], some ART laboratories culture in $5 \% \mathrm{O}_{2}$ [192], which improves mitochondrial membrane potential and upregulates the expression of genes encoding for antioxidant enzymes such as MnSOD and PRDx5 [193]. However, even transient exposure to $21 \% \mathrm{O}_{2}$ at any time during assisted reproduction can compromise the embryo. For example, oocyte culture in $5 \% \mathrm{O}_{2}$ results in higher rates of fertilisation compared to those incubated in $21 \% \mathrm{O}_{2}$ [194] but switches in $\mathrm{O}_{2}$ tension and even temporary removal of oocytes and embryos from low $\mathrm{O}_{2}$ tension to atmospheric causes changes sufficient to induce oxidative stress [194,195]. For example, exposure of mouse zygotes to atmospheric $\mathrm{O}_{2}$ for 1-2 $\mathrm{h}$ reduces the percentage of embryos that reach the blastocyst stage by a third to a half [196].

\subsubsection{Laboratory Light}

Mouse and hamster zygotes exposed to laboratory light for as little as $15 \mathrm{~min}$ have increased $\mathrm{H}_{2} \mathrm{O}_{2}$ and a variety of developmental deficiencies ensue including, in the mouse, an increased percentage of apoptotic cells in the blastocyst and a reduction in live births and, in the hamster, complete cessation of development to the morula stage [197]. Embryos exposed to white light also have lower implantation capacity and a higher percentage of apoptosis and DNA fragmentation, both of which are associated with oxidative stress [198]. Minimising laboratory light poses challenges when performing procedures and monitoring embryo development during IVF and many other forms of ART [197,199]. 


\section{Transgenerational Effects of ROS}

The developmental origins of health and disease hypothesis (DoHaD) states that inappropriate cues in the embryonic environment can result in cellular reprogramming and transcriptional changes, causing disease in offspring up to an including adulthood, and these transcriptional changes potentially have transgenerational effects [200]. The suboptimal environment in which oocytes/embryos are cultured can result in oxidative distress having immediate impact not only on the success rates of assisted reproduction but also long-term effects on fetal, child and adult health and, potentially, the offspring of future generations.

Consistent with this, there is an increase in epigenetic anomalies in children born via ART, some of which are linked to epigenetic changes and imprinting errors. The lack of antioxidants, and enzyme-mediated antioxidant control, in oocyte/embryo culture media can result in ROS-mediated oxidation of methylcytosine, the necessary precursor to active demethylation of DNA at some CpG islands [201]. These immediate and aberrant ROSmediated epigenetic modifications can result in changes to gene expression as well as long-term, including transgenerational, changes $[13,14]$ such as large-offspring syndrome, enlarged organs and metabolic disorders [13].

Cryopreservation exacerbates ROS production in oocytes [93]. In the mouse, the first filial generation offspring derived from cryopreserved oocytes compared to fresh oocytes have increased diastolic blood pressure and increased triglyceride levels as adult mice [12]. Oocytes cryopreserved in the presence of proline have decrease in these transgenerational oxidative stress responses. The mechanisms have not been investigated but proline can act by a number of possible ROS-reducing mechanisms, as outlined above [29,33,34,165-168,202,203]

The endocrine-disruptor, bisphenol A (BPA), can disrupt development via a number of mechanisms including increasing ROS production, altering embryo metabolism and mediating epigenetic modifications. Exposure of bovine oocytes to BPA causes an increase in ROS, decreases oocyte maturation, increases DNA damage and increases histone modifications [204]. Oocytes exposed to BPA in the F0 generation can result in behavioural and other phenotype changes for up to 3 generations [205].

High levels of ROS in sperm can cause epigenetic changes. Obesity results in poorer sperm quality and an increase in spermatic ROS leading to epigenetic changes in the sperm that may be the cause of acquired obesity in future generations [206].

As oxidative stress intensifies, the genetic and epigenetic effects on the gametes increase: Exposure to low levels of oxidative stress causes oxidation of bases and the generation of abasic sites whereas more intense oxidative stress can result in DNA strand breaks [207]. These DNA strand breaks and changes pose a mutagenic risk to the gamete and changes in the nucleus and to DNA can result in mutations in future generations [207].

Collectively, the deficiencies of oocyte/embryo culture media and their inability to properly support protection from oxidative stress, as would normally occur in vivo, results in more frequent changes to the epigenetic landscape [201,208], an increase in the number of offspring with genetic imprinting anomalies, and therefore increased likelihood of transgenerational effects in children and animals born using ART.

\section{Emerging Therapies and Trends in ART}

Some of the relationships between oxidative stress and antioxidants have been fairly well established in animal models including the testing of oral supplementation of antioxidants to reduce ROS levels in follicular and seminal fluids [93,209-225]. Based on this, there have been a number of human clinical trials testing various antioxidants-e.g., melatonin, myoinositol, coenzyme Q10, and multivitamin combinations (principally vitamins $C$ and E) — and their effects on outcomes of assisted reproduction (Table 1).

These listed trials were carried out with patients undergoing fertility treatments, including IVF and ICSI. They aimed to reduce oxidative stress in gametes and embryos, as measured by a number of parameters including fertilisation rate, embryo quality, clinical pregnancy rates, sperm motility and morphology, as well as antioxidant measures 
including TAC, lipid peroxidation (LPO) and antioxidant enzyme levels. Overall, oral supplementation with antioxidants improves the fertilisation rates, embryo quality, and pregnancy rate (Table 1).

Clinical trials are also being carried out testing the exogenous addition of antioxidants to media for sperm, oocyte maturation, fertilisation and embryo culture and their impact on gametes/embryos (Table 2). They aimed to reduce oxidative stress as measured by a number of parameters, including sperm quality, fertilisation rate, embryo development and blastocyst formation. Overall, addition of antioxidants to media results in improved gamete quality and an increase in clinical pregnancies (Table 2).

Given that 21\% (atmospheric) $\mathrm{O}_{2}$ results in increased ROS, many IVF clinics have switched to low $-\mathrm{O}_{2}$ incubators to more closely mimic $\mathrm{O}_{2}$ concentrations of $2-8 \%$ in the reproductive tract $[63,65]$. Several clinical trials have been carried out to determine the impact of low concentrations of $\mathrm{O}_{2}$ on various parameters of fertility [226-228]. Culture of embryos in $5 \% \mathrm{O}_{2}$ increases the percentage developing to the blastocyst stage and their quality. However, there is limited evidence to show low $\mathrm{O}_{2}$ improves live-birth rate [226-228]. 
Table 1. Clinical trials using antioxidants, taken orally, in patients undergoing infertility treatment, and their effect on oocyte, sperm, and embryo health.

\begin{tabular}{|c|c|c|c|c|c|}
\hline Antioxidant & Trial Type & Population & Method & Results & Reference \\
\hline Melatonin & Retrospective & $\begin{array}{l}\text { Women with poor oocyte quality or } \\
\text { low embryo quality in previous } \\
\text { cycles. }\end{array}$ & $\begin{array}{l}3 \mathrm{mg} / \text { day oral melatonin for } \geq 2 \text { weeks until } \\
\text { the day of hCG trigger dose. }\end{array}$ & $\begin{array}{l}\text { Improved fertilisation rates and improved embryo } \\
\text { quality. No effect on oocyte maturation or } \\
\text { percentage of blastocyst development. }\end{array}$ & [209] \\
\hline Melatonin & Randomised clinical trial & Women $20-45$ years undergoing IVF. & $\begin{array}{l}3 \mathrm{mg} / \text { day oral melatonin from the day of } \\
\text { GnRH antagonist until the day of embryo } \\
\text { transfer. }\end{array}$ & $\begin{array}{l}\text { Increased percentage of mature oocytes and grade } 1 \\
\text { embryos. No effect on pregnancy rates }\end{array}$ & [210] \\
\hline Melatonin & Randomised pilot study & $\begin{array}{l}\text { Women with unexplained infertility } \\
\text { undergoing a second IVF cycle. }\end{array}$ & $\begin{array}{l}\text { Groups allocated to } 0,3, \text { or } 6 \mathrm{mg} / \text { day oral } \\
\text { melatonin from first appointment to start of } \\
\text { ovarian stimulation (i.e., } 40 \text { days). }\end{array}$ & $\begin{array}{l}\text { Both doses of melatonin increased levels of } \\
\text { melatonin, TAC, and lipid peroxidation in follicular } \\
\text { fluid; } 6 \mathrm{mg} / \text { day melatonin increased SOD. Both } 3 \\
\text { and } 6 \mathrm{mg} / \text { day melatonin increased the number of } \\
\text { oocytes retrieved, fertilisation percentage, and } \\
\text { number of transferable embryos. }\end{array}$ & [211] \\
\hline Myoinositol and melatonin & $\begin{array}{c}\text { Randomised double-blind clinical } \\
\text { trial }\end{array}$ & $\begin{array}{l}\text { Women with PCOS undergoing IVF } \\
\text { treatment. }\end{array}$ & $\begin{array}{l}\text { Women were allocated to the following groups: } \\
\text { Control, } 4 \mathrm{~g} \text { myoinositol or } 4 \mathrm{~g} \text { myoinositol }+3 \\
\mathrm{mg} \text { melatonin, orally twice per day, from cycle } \\
\text { day } 1 \text { to } 14 \text { days post embryo transfer. }\end{array}$ & $\begin{array}{l}\text { Melatonin increased the percentage of mature } \\
\text { oocytes and number of high-grade embryos. No } \\
\text { effect on pregnancy rate. }\end{array}$ & [212] \\
\hline Myoinositol and melatonin & Prospective clinical trial & $\begin{array}{l}\text { Women aged 30-40 with one or more } \\
\text { unsuccessful IVF cycles due to poor } \\
\text { oocyte quality. }\end{array}$ & $\begin{array}{l}\text { Daily oral supplementation with } 4 \mathrm{~g} \\
\text { myoinositol }+1.8 \text { mg melatonin for } 3 \text { months } \\
\text { prior to IVF cycle. }\end{array}$ & $\begin{array}{c}\text { Increased number of mature oocytes. No effect on } \\
\text { the percentage of mature oocytes, fertilised } \\
\text { embryos, or grade of embryos. }\end{array}$ & [213] \\
\hline Coenzyme Q10 & Randomised control trial & $\begin{array}{l}\text { Women aged }<35 \text {, with poor ovarian } \\
\text { response to stimulation undergoing } \\
\text { IVF } / \text { ICSI. }\end{array}$ & $\begin{array}{l}\text { Oral administration of } 200 \mathrm{mg} \mathrm{CoQ} 103 \text { times } \\
\text { per day for } 60 \text { days prior to IVF/ICSI cycle. }\end{array}$ & $\begin{array}{l}\text { Decreased day } 3 \text { FSH, increased peak E2 } \\
\text { concentration, number of oocytes retrieved, } \\
\text { fertilisation rate, and embryo quality. No effect on } \\
\text { clinical pregnancy rate. }\end{array}$ & [214] \\
\hline Coenzyme Q10 & Controlled clinical study & $\begin{array}{l}\text { Women undergoing IVF-ET for } \\
\text { unexplained or tubal disease-related } \\
\text { infertility. }\end{array}$ & $\begin{array}{l}\text { Oral supplementation of } 200 \mathrm{mg} \text { CoQ } 10 \text { daily } \\
\text { for } 30 \text { days before oocyte pick up. }\end{array}$ & $\begin{array}{l}\text { Increased follicular fluid CoQ10 in its reduced form. } \\
\text { Decreased TAC in patients aged >35 years. }\end{array}$ & [215] \\
\hline Coenzyme Q10 & Retrospective study & $\begin{array}{l}\text { Women with poor ovarian reserve } \\
\text { undergoing IUI or IVF cycles. }\end{array}$ & $\begin{array}{l}\text { Daily oral administration of either } 75 \mathrm{mg} \\
\text { DHEA alone or } 75 \mathrm{mg} \text { DHEA + } 600 \mathrm{mg} \text { CoQ10. }\end{array}$ & $\begin{array}{l}\text { Improved ovarian responsiveness with an increase } \\
\text { in antral follicular count and number of mature } \\
\text { follicles. No change in blastocyst development or } \\
\text { pregnancy rates. }\end{array}$ & [216] \\
\hline Growth hormone & Randomised control clinical trial & $\begin{array}{l}\text { Women with poor ovarian reserve } \\
\text { undergoing IVF. }\end{array}$ & $\begin{array}{l}4 \mathrm{IU} / \text { day growth hormone injected } \\
\text { subcutaneously from day } 2 \text { of the previous } \\
\text { menstrual cycle until trigger day (36-48 days). }\end{array}$ & $\begin{array}{c}\text { Increased endometrial thickness, implantation rate, } \\
\text { and clinical pregnancy. Increased TAC, decreased } \\
\text { total oxidative stress index in follicular fluid. } \\
\text { Decreased ROS in granulosa cells. Increased } \\
\text { embryo quality, implantation rate, and clinical } \\
\text { pregnancies. }\end{array}$ & [217] \\
\hline N-acetyl cysteine (NAC) & $\begin{array}{l}\text { Placebo-controlled double-blind, } \\
\text { randomised clinical trial }\end{array}$ & Women with PCOS undergoing IVF. & $\begin{array}{l}\text { Oral administration of } 1.2 \mathrm{~g} \mathrm{NAC} \text { on days } 3-7 \\
\text { of the menstrual cycle. }\end{array}$ & $\begin{array}{l}\text { Increased number of follicles, ovulation rate, } \\
\text { pregnancy rate, and endometrial thickness. }\end{array}$ & [218] \\
\hline Pentoxifylline and vitamin $\mathrm{E}$ & Randomised clinical trial & $\begin{array}{l}\text { Women }<39 \text { years of age with various } \\
\text { forms of infertility undergoing } \\
\text { ICSI-ZIFT. }\end{array}$ & $\begin{array}{l}\text { Daily oral administration of } 400 \mathrm{mg} \text { vitamin } \mathrm{E} \\
\text { and } 400 \mathrm{mg} \text { pentoxifylline for two cycles } \\
\text { before ZIFT. }\end{array}$ & Improved clinical pregnancy rate. & {$[224,229]$} \\
\hline Multivitamin and mineral & Controlled clinical trial & $\begin{array}{l}\text { Women undergoing infertility } \\
\text { treatment. }\end{array}$ & $\begin{array}{l}\text { Oral multivitamin and mineral } \\
\text { supplementation for } 45 \text { days before oocyte } \\
\text { collection. }\end{array}$ & $\begin{array}{l}\text { Decreased lipid peroxidase levels in follicular fluid } \\
\text { and serum. Increased GSH and vitamins C and E in } \\
\text { follicular fluid. }\end{array}$ & [219] \\
\hline
\end{tabular}


Table 1. Cont.

\begin{tabular}{|c|c|c|c|c|c|}
\hline Antioxidant & Trial Type & Population & Method & Results & Reference \\
\hline $\begin{array}{c}\text { FertiMax2 } \\
\text { (Vitamins C and E, zinc, selenium, } \\
\text { L-carnitine, folic acid, and coenzyme } \\
\text { Q10) }\end{array}$ & Preliminary clinical study & $\begin{array}{l}\text { Males with male factor infertility } \\
\text { undergoing IVF/ICSI. }\end{array}$ & $\begin{array}{l}\text { Oral administration of Fertimax } 2 \text { for } 2-5 \\
\text { months prior to partner's IVF/ICSI cycle. }\end{array}$ & $\begin{array}{l}\text { Increased fertilisation, cleavage, embryo quality, } \\
\text { implantation, and clinical pregnancy rate. } \\
\text { No effect on semen parameters. }\end{array}$ & [220] \\
\hline $\begin{array}{l}\text { Menevit } \\
\text { (Lycopene, vitamins } C \text { and E, zinc, } \\
\text { selenium, folate, garlic oil) }\end{array}$ & Retrospective cohort analysis & $\begin{array}{l}\text { Males with male factor infertility } \\
\text { undergoing IVF/ICSI. }\end{array}$ & $\begin{array}{l}\text { Single daily capsule for an unrecorded amount } \\
\text { of time. }\end{array}$ & Increased clinical pregnancy and live birth rate. & [225] \\
\hline $\begin{array}{l}\text { Micronutrient antioxidants } \\
\text { (Vitamins, folates and minerals) }\end{array}$ & Preliminary study & $\begin{array}{l}\text { Women aged }>39 \text { years undergoing } \\
\text { infertility treatments with one failed } \\
\text { embryo transfer. }\end{array}$ & $\begin{array}{l}\text { After one typical GnRH antagonist cycle, failed } \\
\text { patients were prescribed a daily capsule of } \\
\text { micronutrient antioxidants for three months } \\
\text { before embryo transfer. }\end{array}$ & $\begin{array}{l}\text { Increased TAC and free thiol availability in } \\
\text { follicular fluid and serum. Decreased number of } \\
\text { poor grade embryos. No change in fertilisation or } \\
\text { cleavage rates. }\end{array}$ & [222] \\
\hline $\begin{array}{l}\text { Mixed antioxidant formulation } \\
\text { (Vitamins C and E, selenium, } \\
\text { L-carnitine, zinc, folic acid, lycopene) }\end{array}$ & Randomised controlled trial & $\begin{array}{l}\text { Males with either low sperm } \\
\text { concentration, motility, morphology } \\
\text { or high DNA fragmentation. }\end{array}$ & $\begin{array}{l}\text { Allocated antioxidant or placebo for 3-6 } \\
\text { months. Semen parameters including } \\
\text { concentration, motility, morphology, and DNA } \\
\text { fragmentation measured. }\end{array}$ & $\begin{array}{l}\text { Decreased sperm concentration, total sperm count, } \\
\text { and total motile sperm. No change in morphology, } \\
\text { motility, or DNA fragmentation. No change in } \\
\text { pregnancy/live birth rates. }\end{array}$ & [223] \\
\hline
\end{tabular}

Table 2. Clinical trials using antioxidants in vitro and their effect on oocyte, sperm, and embryo health.

\begin{tabular}{|c|c|c|c|c|c|}
\hline Antioxidant & Trial Type & Population & Method & Results & Reference \\
\hline $\begin{array}{l}\text { Mixed antioxidant formulation } \\
\text { (acetyl-L-carnitine, N-acetyl cysteine, } \\
\text { alpha-lipoic acid) }\end{array}$ & $\begin{array}{l}\text { Blinded randomised control } \\
\text { sibling oocyte study }\end{array}$ & $\begin{array}{l}\text { IVF/ICSI patients under } 40 \text { years } \\
\text { undergoing fertility treatment. }\end{array}$ & $\begin{array}{l}\text { Formulation added to G-series medium, } \\
\text { including } 10 \mu \mathrm{M} \text { acetyl-L-carnitine, } 10 \mu \mathrm{M} \\
\mathrm{N} \text {-acetylcysteine, and } 5 \mu \mathrm{M} \text { alpha-lipoic acid } \\
\text { added to both fertilisation and culture media. }\end{array}$ & $\begin{array}{l}\text { No effect on fertilisation. Increased percentage of } \\
\text { good quality embryos on day } 3 \text { (patients }<35 \text { years). } \\
\text { Increased number of patients ( } 35-40 \text { years) receiving a } \\
\text { positive pregnancy test, increased percentage with } \\
\text { fetal heart beat and ongoing pregnancy. }\end{array}$ & [230] \\
\hline L-carnitine & Retrospective clinical trial & $\begin{array}{l}\text { Patients }<40 \text { years undergoing } \\
\text { infertility treatment. }\end{array}$ & $\begin{array}{l}1 \mathrm{mM} \text { L-carnitine added to embryo culture } \\
\text { medium from day } 1 \text { to day } 6 \text {. }\end{array}$ & $\begin{array}{l}\text { No effect on percentage of embryos developed to } \\
\text { blastocyst stage but increased percentage of good } \\
\text { quality embryos on days 2,3, and } 5 \text {. Increased } \\
\text { blastocyst ICM and TE cell numbers and increased } \\
\text { clinical and ongoing pregnancies. }\end{array}$ & [231] \\
\hline $\begin{array}{c}\text { Mixed antioxidants } \\
\text { (L-carnitine, taurine vitamin B5, } \\
\text { vitamin C; other vitamins that are not } \\
\text { antioxidants were also added to this } \\
\text { formulation) }\end{array}$ & $\begin{array}{l}\text { Non-interventional sibling } \\
\text { oocyte study }\end{array}$ & $\begin{array}{l}\text { Women } \leq 42 \text { years old undergoing } \\
\text { ICSI cycles. }\end{array}$ & $\begin{array}{l}\text { Oocytes randomly allocated to medium } \\
\text { containing mixed antioxidants or standard } \\
\text { continuous single culture medium. }\end{array}$ & $\begin{array}{c}\text { Antioxidant containing medium had no effect on } \\
\text { blastulation but showed slower compaction and } \\
\text { blastulation rates, and blastocysts were of poorer } \\
\text { quality. }\end{array}$ & [233] \\
\hline Alpha-lipoic acid & Randomised clinical trial & $\begin{array}{l}\text { Normozoospermic men undergoing } \\
\text { IVF/ICSI cycles. }\end{array}$ & $\begin{array}{l}\text { Semen samples were randomly allocated to } \\
\text { sperm wash medium } \pm 0.02 \mathrm{mM} \text { alpha-lipoic acid } \\
\text { during centrifugation and incubation for } 1 \mathrm{~h} \text {. }\end{array}$ & $\begin{array}{l}\text { Sperm viability and motility increased while DNA } \\
\text { damage and ROS decreased when prepared in wash } \\
\text { medium containing alpha-lipoic acid. }\end{array}$ & [234] \\
\hline
\end{tabular}




\section{Conclusions}

This review highlights that ROS and oxidative eustress contribute to normal cellular homeostasis, with ROS playing direct and indirect roles in a very wide range of physiological processes. In keeping with this, homeostatic levels of ROS, including timed bursts, are necessary for normal oocyte maturation, fertilisation and embryo development. However, excess ROS production results in tipping the redox balance from eustress to distress, leaving oocytes and embryos susceptible to damage, particularly in the in vitro environment where protective maternal factors are absent. Highly simplified culture media, and non-physiological culture conditions (including high oxygen tension and exposure to laboratory light) contribute to reduced success for ART. Oxidative distress disrupts metabolic and signalling pathways, alters the expression of wide range of genes, and changes the epigenetic landscape. These disruptions not only affect the oocyte/embryo but can have transgenerational impacts.

Animal models and clinical trials show that judicious exogenous addition of antioxidants to culture media or oral supplementation to diet can mitigate the impact of ROS and improve assisted reproduction outcomes. Similarly, the addition of antioxidants to in vitro media for gamete preparation and cryopreservation can be beneficial to future embryo development. Nevertheless, the extraordinary complexity of the redox circuitry in vivo means much remains to be understood and applied to improve the success in ART.

Author Contributions: M.L.M.H., M.L.D. and M.B.M. all researched, wrote, and edited the manuscript. All authors have read and agreed to the published version of the manuscript.

Funding: This research received no external funding.

Institutional Review Board Statement: Not applicable.

Informed Consent Statement: Not applicable.

Data Availability Statement: No new data were created or analysed in this study. Data sharing is not applicable to this article.

Conflicts of Interest: The authors declare no conflict of interest.

\section{References}

1. Dumollard, R.; Duchen, M.; Carroll, J. The role of mitochondrial function in the oocyte and embryo. Curr. Top. Dev. Biol. 2007, 77, 21-49. [CrossRef]

2. Harvey, A.J.; Kind, K.L.; Thompson, J.G. REDOX regulation of early embryo development. Reproduction 2002, 123, 479-486. [CrossRef]

3. Schafer, F.Q.; Buettner, G.R. Redox environment of the cell as viewed through the redox state of the glutathione disulfide/glutathione couple. Free Radic. Biol. Med. 2001, 30, 1191-1212. [CrossRef]

4. Sies, H.; Jones, D.P. Reactive oxygen species (ROS) as pleiotropic physiological signalling agents. Nat. Rev. Mol. Cell Biol. 2020, 21, 363-383. [CrossRef]

5. Sies, H. Oxidative Stress. In Stress: Physiology, Biochemistry, and Pathology; Fink, G., Ed.; Academic Press: Cambridge, MA, USA, 2019; pp. 153-163. [CrossRef]

6. Sies, H.; Chance, B. The steady state level of catalase compound I in isolated hemoglobin-free perfused rat liver. FEBS Lett. 1970, 11, 172-176. [CrossRef]

7. Harper, M.E.; Bevilacqua, L.; Hagopian, K.; Weindruch, R.; Ramsey, J.J. Ageing, oxidative stress, and mitochondrial uncoupling. Acta Physiol. Scand. 2004, 182, 321-331. [CrossRef]

8. Mailloux, R.J.; Jin, X.; Willmore, W.G. Redox regulation of mitochondrial function with emphasis on cysteine oxidation reactions. Redox Biol. 2014, 2, 123-139. [CrossRef]

9. Boveris, A.; Chance, B. The mitochondrial generation of hydrogen peroxide. General properties and effect of hyperbaric oxygen. Biochem. J. 1973, 134, 707-716. [CrossRef]

10. Arrigo, A.P. Gene expression and the thiol redox state. Free Radic. Biol. Med. 1999, 27, 936-944. [CrossRef]

11. Guerin, P.; El Mouatassim, S.; Menezo, Y. Oxidative stress and protection against reactive oxygen species in the pre-implantation embryo and its surroundings. Hum. Reprod. Update 2001, 7, 175-189. [CrossRef] [PubMed]

12. Huo, Y.; Qin, Q.; Zhang, L.; Kuo, Y.; Wang, H.; Yan, L.; Li, R.; Zhang, X.; Yan, J.; Qiao, J. Effects of oocyte vitrification on the behaviors and physiological indexes of aged first filial generation mice. Cryobiology 2020, 95, 20-28. [CrossRef] [PubMed] 
13. Calle, A.; Fernandez-Gonzalez, R.; Ramos-Ibeas, P.; Laguna-Barraza, R.; Perez-Cerezales, S.; Bermejo-Alvarez, P.; Ramirez, M.A.; Gutierrez-Adan, A. Long-term and transgenerational effects of in vitro culture on mouse embryos. Theriogenology 2012, 77, 785-793. [CrossRef]

14. Ruebel, M.L.; Latham, K.E. Listening to mother: Long-term maternal effects in mammalian development. Mol. Reprod. Dev. 2020, 87, 399-408. [CrossRef] [PubMed]

15. Li, R.; Jia, Z.; Trush, M.A. Defining ROS in Biology and Medicine. React. Oxyg. Species (Apex) 2016, 1, 9-21. [CrossRef]

16. Onyango, A.N. Endogenous Generation of Singlet Oxygen and Ozone in Human and Animal Tissues: Mechanisms, Biological Significance, and Influence of Dietary Components. Oxid. Med. Cell. Longev. 2016, 2016, 2398573. [CrossRef]

17. Pisoschi, A.M.; Pop, A. The role of antioxidants in the chemistry of oxidative stress: A review. Eur. J. Med. Chem. 2015, 97, 55-74. [CrossRef]

18. He, A.; Dean, J.M.; Lodhi, I.J. Peroxisomes as cellular adaptors to metabolic and environmental stress. Trends Cell Biol. 2021, 31, 656-670. [CrossRef]

19. Ryter, S.W.; Kim, H.P.; Hoetzel, A.; Park, J.W.; Nakahira, K.; Wang, X.; Choi, A.M. Mechanisms of cell death in oxidative stress. Antioxid. Redox Signal. 2007, 9, 49-89. [CrossRef]

20. Di Meo, S.; Reed, T.T.; Venditti, P.; Victor, V.M. Role of ROS and RNS Sources in Physiological and Pathological Conditions. Oxid. Med. Cell. Longev. 2016, 2016, 1245049. [CrossRef]

21. Panday, A.; Sahoo, M.K.; Osorio, D.; Batra, S. NADPH oxidases: An overview from structure to innate immunity-associated pathologies. Cell. Mol. Immunol. 2015, 12, 5-23. [CrossRef] [PubMed]

22. Kodaman, P.H.; Behrman, H.R. Endocrine-regulated and protein kinase C-dependent generation of superoxide by rat preovulatory follicles. Endocrinology 2001, 142, 687-693. [CrossRef] [PubMed]

23. Ufer, C.; Wang, C.C.; Borchert, A.; Heydeck, D.; Kuhn, H. Redox control in mammalian embryo development. Antioxid. Redox Signal. 2010, 13, 833-875. [CrossRef]

24. Liu, Y.; Fiskum, G.; Schubert, D. Generation of reactive oxygen species by the mitochondrial electron transport chain. J. Neurochem. 2002, 80, 780-787. [CrossRef]

25. Oshino, N.; Chance, B.; Sies, $\mathrm{H} . ;$ Bücher, T. The role of $\mathrm{H}_{2} \mathrm{O}_{2}$ generation in perfused rat liver and the reaction of catalase compound I and hydrogen donors. Arch. Biochem. Biophys. 1973, 154, 117-131. [CrossRef]

26. Murphy, M.P. How mitochondria produce reactive oxygen species. Biochem. J. 2009, 417, 1-13. [CrossRef]

27. Turrens, J.F. Mitochondrial formation of reactive oxygen species. J. Physiol. 2003, 552, 335-344. [CrossRef] [PubMed]

28. Cadenas, E.; Davies, K.J. Mitochondrial free radical generation, oxidative stress, and aging. Free Radic. Biol. Med. 2000, 29, 222-230. [CrossRef]

29. Hancock, C.N.; Liu, W.; Alvord, W.G.; Phang, J.M. Co-regulation of mitochondrial respiration by proline dehydrogenase/oxidase and succinate. Amino Acids 2016, 48, 859-872. [CrossRef] [PubMed]

30. Goncalves, R.L.; Rothschild, D.E.; Quinlan, C.L.; Scott, G.K.; Benz, C.C.; Brand, M.D. Sources of superoxide/H2O2 during mitochondrial proline oxidation. Redox Biol. 2014, 2, 901-909. [CrossRef]

31. Pandhare, J.; Donald, S.P.; Cooper, S.K.; Phang, J.M. Regulation and function of proline oxidase under nutrient stress. J. Cell. Biochem. 2009, 107, 759-768. [CrossRef]

32. Phang, J.M.; Donald, S.P.; Pandhare, J.; Liu, Y. The metabolism of proline, a stress substrate, modulates carcinogenic pathways. Amino Acids 2008, 35, 681-690. [CrossRef]

33. Phang, J. The regulatory functions of proline and pyrroline-5-carboxylic acid. Curr. Top. Cell. Regul. 1985, 25, 91-132. [PubMed]

34. Phang, J.M.; Yeh, G.C.; Hagedorn, C.H. The intercellular proline cycle. Life Sci. 1981, 28, 53-58. [CrossRef]

35. Natarajan, S.K.; Zhu, W.; Liang, X.; Zhang, L.; Demers, A.J.; Zimmerman, M.C.; Simpson, M.A.; Becker, D.F. Proline dehydrogenase is essential for proline protection against hydrogen peroxide-induced cell death. Free Radic. Biol. Med. 2012, 53, $1181-1191$. [CrossRef]

36. Wong, H.S.; Benoit, B.; Brand, M.D. Mitochondrial and cytosolic sources of hydrogen peroxide in resting C2C12 myoblasts. Free Radic. Biol. Med. 2019, 130, 140-150. [CrossRef]

37. Rampon, C.; Volovitch, M.; Joliot, A.; Vriz, S. Hydrogen Peroxide and Redox Regulation of Developments. Antioxidants 2018, 7 , 159. [CrossRef] [PubMed]

38. Dutta, S.; Henkel, R.; Sengupta, P.; Agarwal, A. Physiological role of ROS in sperm function. In Male Infertility; Springer: Cham, Switzerland, 2020; pp. 337-345.

39. Ray, P.D.; Huang, B.W.; Tsuji, Y. Reactive oxygen species (ROS) homeostasis and redox regulation in cellular signaling. Cell. Signal. 2012, 24, 981-990. [CrossRef]

40. Mailloux, R.J.; McBride, S.L.; Harper, M.E. Unearthing the secrets of mitochondrial ROS and glutathione in bioenergetics. Trends Biochem. Sci. 2013, 38, 592-602. [CrossRef] [PubMed]

41. Harris, C.; Hansen, J.M. Oxidative stress, thiols, and redox profiles. In Developmental Toxicology; Humana Press: Totowa, NJ, USA, 2012; pp. 325-346.

42. Reczek, C.R.; Chandel, N.S. ROS-dependent signal transduction. Curr. Opin. Cell Biol. 2015, 33, 8-13. [CrossRef]

43. Essers, M.A.; Weijzen, S.; de Vries-Smits, A.M.; Saarloos, I.; de Ruiter, N.D.; Bos, J.L.; Burgering, B.M. FOXO transcription factor activation by oxidative stress mediated by the small GTPase Ral and JNK. EMBO J. 2004, 23, 4802-4812. [CrossRef] [PubMed] 
44. Burhans, W.C.; Heintz, N.H. The cell cycle is a redox cycle: Linking phase-specific targets to cell fate. Free Radic. Biol. Med. 2009, 47, 1282-1293. [CrossRef] [PubMed]

45. Klotz, L.O.; Sanchez-Ramos, C.; Prieto-Arroyo, I.; Urbanek, P.; Steinbrenner, H.; Monsalve, M. Redox regulation of FoxO transcription factors. Redox Biol. 2015, 6, 51-72. [CrossRef] [PubMed]

46. Veal, E.A.; Day, A.M.; Morgan, B.A. Hydrogen peroxide sensing and signaling. Mol. Cell 2007, 26, 1-14. [CrossRef]

47. Fourquet, S.; Guerois, R.; Biard, D.; Toledano, M.B. Activation of NRF2 by nitrosative agents and $\mathrm{H} 2 \mathrm{O} 2$ involves KEAP1 disulfide formation. J. Biol. Chem. 2010, 285, 8463-8471. [CrossRef] [PubMed]

48. Kobayashi, Y.; Oguro, A.; Imaoka, S. Feedback of hypoxia-inducible factor-1alpha (HIF-1alpha) transcriptional activity via redox factor-1 (Ref-1) induction by reactive oxygen species (ROS). Free Radic. Res. 2021, 55, 154-164. [CrossRef]

49. Chan, D.A.; Sutphin, P.D.; Yen, S.-E.; Giaccia, A.J. Coordinate regulation of the oxygen-dependent degradation domains of hypoxia-inducible factor $1 \alpha$. Mol. Cell. Biol. 2005, 25, 6415-6426. [CrossRef] [PubMed]

50. Dengler, V.L.; Galbraith, M.; Espinosa, J.M. Transcriptional regulation by hypoxia inducible factors. Crit. Rev. Biochem. Mol. Biol. 2014, 49, 1-15. [CrossRef]

51. Liu, H.; Colavitti, R.; Rovira, I.I.; Finkel, T. Redox-dependent transcriptional regulation. Circ. Res. 2005, 97, 967-974. [CrossRef]

52. Kumari, S.; Badana, A.K.; G, M.M.; G, S.; Malla, R. Reactive Oxygen Species: A Key Constituent in Cancer Survival. Biomark. Insights 2018, 13, 1177271918755391. [CrossRef]

53. Moloney, J.N.; Cotter, T.G. ROS signalling in the biology of cancer. Semin. Cell Dev. Biol. 2018, 80, 50-64. [CrossRef] [PubMed]

54. Roy, K.; Wu, Y.; Meitzler, J.L.; Juhasz, A.; Liu, H.; Jiang, G.; Lu, J.; Antony, S.; Doroshow, J.H. NADPH oxidases and cancer. Clin. Sci. 2015, 128, 863-875. [CrossRef] [PubMed]

55. Rocha, M.; Apostolova, N.; Herance, J.R.; Rovira-Llopis, S.; Hernandez-Mijares, A.; Victor, V.M. Perspectives and potential applications of mitochondria-targeted antioxidants in cardiometabolic diseases and type 2 diabetes. Med. Res. Rev. 2014, 34, 160-189. [CrossRef]

56. Fiaschi, T.; Chiarugi, P. Oxidative stress, tumor microenvironment, and metabolic reprogramming: A diabolic liaison. Int. J. Cell Biol. 2012, 2012, 762825. [CrossRef]

57. Giorgi, C.; Danese, A.; Missiroli, S.; Patergnani, S.; Pinton, P. Calcium dynamics as a machine for decoding signals. Trends Cell Biol. 2018, 28, 258-273. [CrossRef] [PubMed]

58. Gorlach, A.; Bertram, K.; Hudecova, S.; Krizanova, O. Calcium and ROS: A mutual interplay. Redox Biol. $2015,6,260-271$. [CrossRef]

59. Sharov, V.S.; Dremina, E.S.; Galeva, N.A.; Williams, T.D.; Schoneich, C. Quantitative mapping of oxidation-sensitive cysteine residues in SERCA in vivo and in vitro by HPLC-electrospray-tandem MS: Selective protein oxidation during biological aging. Biochem. J. 2006, 394, 605-615. [CrossRef] [PubMed]

60. Higaki, Y.; Mikami, T.; Fujii, N.; Hirshman, M.F.; Koyama, K.; Seino, T.; Tanaka, K.; Goodyear, L.J. Oxidative stress stimulates skeletal muscle glucose uptake through a phosphatidylinositol 3-kinase-dependent pathway. Am. J. Physiol. Endocrinol. Metab. 2008, 294, E889-E897. [CrossRef] [PubMed]

61. Kozlovsky, N.; Rudich, A.; Potashnik, R.; Ebina, Y.; Murakami, T.; Bashan, N. Transcriptional activation of the Glut1 gene in response to oxidative stress in L6 myotubes. J. Biol. Chem. 1997, 272, 33367-33372. [CrossRef]

62. Fischer, B.; Kunzel, W.; Kleinstein, J.; Gips, H. Oxygen tension in follicular fluid falls with follicle maturation. Eur. J. Obstet. Gynecol. Reprod. Biol. 1992, 43, 39-43. [CrossRef]

63. Fischer, B.; Bavister, B.D. Oxygen tension in the oviduct and uterus of rhesus monkeys, hamsters and rabbits. J. Reprod. Fertil. 1993, 99, 673-679. [CrossRef]

64. Lim, M.; Thompson, J.G.; Dunning, K.R. Hypoxia and ovarian function: Follicle development, ovulation, oocyte maturation. Reproduction 2021, 161, F33-F40. [CrossRef] [PubMed]

65. Morin, S.J. Oxygen tension in embryo culture: Does a shift to $2 \% \mathrm{O} 2$ in extended culture represent the most physiologic system? J. Assist. Reprod. Genet. 2017, 34, 309-314. [CrossRef]

66. El Mouatassim, S.; Guerin, P.; Menezo, Y. Mammalian oviduct and protection against free oxygen radicals: Expression of genes encoding antioxidant enzymes in human and mouse. Eur. J. Obstet. Gynecol. Reprod. Biol. 2000, 89, 1-6. [CrossRef]

67. Ambekar, A.S.; Nirujogi, R.S.; Srikanth, S.M.; Chavan, S.; Kelkar, D.S.; Hinduja, I.; Zaveri, K.; Prasad, T.S.; Harsha, H.C.; Pandey, A.; et al. Proteomic analysis of human follicular fluid: A new perspective towards understanding folliculogenesis. J. Proteom. 2013, 87, 68-77. [CrossRef]

68. Agarwal, A.; Aponte-Mellado, A.; Premkumar, B.J.; Shaman, A.; Gupta, S. The effects of oxidative stress on female reproduction: A review. Reprod. Biol. Endocrinol. 2012, 10, 49. [CrossRef] [PubMed]

69. El Mouatassim, S.; Guerin, P.; Menezo, Y. Expression of genes encoding antioxidant enzymes in human and mouse oocytes during the final stages of maturation. Mol. Hum. Reprod. 1999, 5, 720-725. [CrossRef]

70. Ozawa, M.; Nagai, T.; Somfai, T.; Nakai, M.; Maedomari, N.; Miyazaki, H.; Kaneko, H.; Noguchi, J.; Kikuchi, K. Cumulus cell-enclosed oocytes acquire a capacity to synthesize GSH by FSH stimulation during in vitro maturation in pigs. J. Cell. Physiol. 2010, 222, 294-301. [CrossRef]

71. Nasr-Esfahani, M.H.; Aitken, J.R.; Johnson, M.H. Hydrogen peroxide levels in mouse oocytes and early cleavage stage embryos developed in vitro or in vivo. Development 1990, 109, 501-507. [CrossRef] [PubMed] 
72. Lane, M.; Gardner, D.K. Embryo culture medium: Which is the best? Best Pract. Res. Clin. Obstet. Gynaecol. 2007, 21, 83-100. [CrossRef]

73. Gardner, D.K.; Sakkas, D. Mouse embryo cleavage, metabolism and viability: Role of medium composition. Hum. Reprod. 1993, 8, 288-295. [CrossRef]

74. Biggers, J.D. Thoughts on embryo culture conditions. Reprod. Biomed. Online 2002, 4 (Suppl. 1), 30-38. [CrossRef]

75. Martin-Romero, F.J.; Miguel-Lasobras, E.M.; Dominguez-Arroyo, J.A.; Gonzalez-Carrera, E.; Alvarez, I.S. Contribution of culture media to oxidative stress and its effect on human oocytes. Reprod. Biomed. Online 2008, 17, 652-661. [CrossRef]

76. Orsi, N.M.; Leese, H.J. Amino acid metabolism of preimplantation bovine embryos cultured with bovine serum albumin or polyvinyl alcohol. Theriogenology 2004, 61, 561-572. [CrossRef]

77. Palasz, A.; Tornesi, M.; Archer, J.; Mapletoft, R. Media alternatives for the collection, culture and freezing of mouse and cattle embryos. Theriogenology 1995, 44, 705-714. [CrossRef]

78. O'Flaherty, C.; de Lamirande, E.; Gagnon, C. Reactive oxygen species modulate independent protein phosphorylation pathways during human sperm capacitation. Free Radic. Biol. Med. 2006, 40, 1045-1055. [CrossRef]

79. Freitas, C.; Neto, A.C.; Matos, L.; Silva, E.; Ribeiro, A.; Silva-Carvalho, J.L.; Almeida, H. Follicular Fluid redox involvement for ovarian follicle growth. J. Ovarian Res. 2017, 10, 44. [CrossRef]

80. de Matos, D.G.; Furnus, C.C.; Moses, D.F. Glutathione Synthesis During in Vitro Maturation of Bovine Oocytes: Role of Cumulus Cells1. Biol. Reprod. 1997, 57, 1420-1425. [CrossRef]

81. Agarwal, A.; Gupta, S.; Sekhon, L.; Shah, R. Redox considerations in female reproductive function and assisted reproduction: From molecular mechanisms to health implications. Antioxid. Redox Signal. 2008, 10, 1375-1403. [CrossRef] [PubMed]

82. Kala, M.; Shaikh, M.V.; Nivsarkar, M. Equilibrium between anti-oxidants and reactive oxygen species: A requisite for oocyte development and maturation. Reprod. Med. Biol. 2017, 16, 28-35. [CrossRef]

83. Tripathi, A.; Khatun, S.; Pandey, A.N.; Mishra, S.K.; Chaube, R.; Shrivastav, T.G.; Chaube, S.K. Intracellular levels of hydrogen peroxide and nitric oxide in oocytes at various stages of meiotic cell cycle and apoptosis. Free Radic. Res. 2009, 43, 287-294. [CrossRef] [PubMed]

84. Gupta, S.; Choi, A.; Yu, H.Y.; Czerniak, S.M.; Holick, E.A.; Paolella, L.J.; Agarwal, A.; Combelles, C.M. Fluctuations in total antioxidant capacity, catalase activity and hydrogen peroxide levels of follicular fluid during bovine folliculogenesis. Reprod. Fertil. Dev. 2011, 23, 673-680. [CrossRef]

85. Rubio, C.P.; Hernandez-Ruiz, J.; Martinez-Subiela, S.; Tvarijonaviciute, A.; Ceron, J.J. Spectrophotometric assays for total antioxidant capacity (TAC) in dog serum: An update. BMC Vet. Res. 2016, 12, 166. [CrossRef] [PubMed]

86. Das, S.; Chattopadhyay, R.; Ghosh, S.; Ghosh, S.; Goswami, S.K.; Chakravarty, B.N.; Chaudhury, K. Reactive oxygen species level in follicular fluid-embryo quality marker in IVF? Hum. Reprod. 2006, 21, 2403-2407. [CrossRef]

87. Jancar, N.; Kopitar, A.N.; Ihan, A.; Virant Klun, I.; Bokal, E.V. Effect of apoptosis and reactive oxygen species production in human granulosa cells on oocyte fertilization and blastocyst development. J. Assist. Reprod. Genet. 2007, 24, 91-97. [CrossRef] [PubMed]

88. Jana, S.K.; Babu, N.; Chattopadhyay, R.; Chakravarty, B.; Chaudhury, K. Upper control limit of reactive oxygen species in follicular fluid beyond which viable embryo formation is not favorable. Reprod. Toxicol. 2010, 29, 447-451. [CrossRef] [PubMed]

89. Salimi, M.; Mozdarani, H. Effect of vitamin E on preovulatory stage irradiated female mouse expressed as chromosomal abnormalities in generated embryos. Iran. J. Radiat. Res 2006, 4, 35-40.

90. Baumber, J.; Ball, B.A.; Linfor, J.J.; Meyers, S.A. Reactive oxygen species and cryopreservation promote DNA fragmentation in equine spermatozoa. J. Androl. 2003, 24, 621-628. [CrossRef]

91. Lane, M.; McPherson, N.O.; Fullston, T.; Spillane, M.; Sandeman, L.; Kang, W.X.; Zander-Fox, D.L. Oxidative stress in mouse sperm impairs embryo development, fetal growth and alters adiposity and glucose regulation in female offspring. PLoS ONE 2014, 9, e100832. [CrossRef]

92. Ruihuan, G.; Zhichao, L.; Song, G.; Jing, F.; Yijuan, S.; Xiaoxi, S. Oocyte Vitrification Temporarily Turns on Oxidation-Reduction Process Genes in Mouse Preimplantation Embryos. Reprod. Sci. 2021, 28, 1307-1315. [CrossRef]

93. Zhang, L.; Xue, X.; Yan, J.; Yan, L.Y.; Jin, X.H.; Zhu, X.H.; He, Z.Z.; Liu, J.; Li, R.; Qiao, J. L-proline: A highly effective cryoprotectant for mouse oocyte vitrification. Sci. Rep. 2016, 6, 26326. [CrossRef]

94. Wang, F.; Tian, X.; Zhou, Y.; Tan, D.; Zhu, S.; Dai, Y.; Liu, G. Melatonin improves the quality of in vitro produced (IVP) bovine embryos: Implications for blastocyst development, cryotolerance, and modifications of relevant gene expression. PLoS ONE 2014, 9, e93641. [CrossRef]

95. Gupta, M.K.; Uhm, S.J.; Lee, H.T. Effect of vitrification and beta-mercaptoethanol on reactive oxygen species activity and in vitro development of oocytes vitrified before or after in vitro fertilization. Fertil. Steril. 2010, 93, 2602-2607. [CrossRef]

96. Kattera, S.; Chen, C. Short coincubation of gametes in in vitro fertilization improves implantation and pregnancy rates: A prospective, randomized, controlled study. Fertil. Steril. 2003, 80, 1017-1021. [CrossRef]

97. Harris, S.E.; Leese, H.J.; Gosden, R.G.; Picton, H.M. Pyruvate and oxygen consumption throughout the growth and development of murine oocytes. Mol. Reprod. Dev. 2009, 76, 231-238. [CrossRef] [PubMed]

98. Rieger, D.; Loskutoff, N. Changes in the metabolism of glucose, pyruvate, glutamine and glycine during maturation of cattle oocytes in vitro. Reproduction 1994, 100, 257-262. [CrossRef]

99. Tiwari, M.; Chaube, S.K. Moderate increase of reactive oxygen species triggers meiotic resumption in rat follicular oocytes. J. Obstet. Gynaecol. Res. 2016, 42, 536-546. [CrossRef] [PubMed] 
100. Pandey, A.N.; Chaube, S.K. A moderate increase of hydrogen peroxide level is beneficial for spontaneous resumption of meiosis from diplotene arrest in rat oocytes cultured in vitro. BioResearch Open Access 2014, 3, 183-191. [CrossRef]

101. Park, Y.S.; You, S.Y.; Cho, S.; Jeon, H.-J.; Lee, S.; Cho, D.-H.; Kim, J.-S.; Oh, J.S. Eccentric localization of catalase to protect chromosomes from oxidative damages during meiotic maturation in mouse oocytes. Histochem. Cell Biol. 2016, 146, 281-288. [CrossRef]

102. Shkolnik, K.; Tadmor, A.; Ben-Dor, S.; Nevo, N.; Galiani, D.; Dekel, N. Reactive oxygen species are indispensable in ovulation. Proc. Natl. Acad. Sci. USA 2011, 108, 1462-1467. [CrossRef] [PubMed]

103. Takami, M.; Preston, S.L.; Toyloy, V.A.; Behrman, H.R. Antioxidants reversibly inhibit the spontaneous resumption of meiosis. Am. J. Physiol. 1999, 276, E684-E688. [CrossRef] [PubMed]

104. Lopes, A.; Lane, M.; Thompson, J. Oxygen consumption and ROS production are increased at the time of fertilization and cell cleavage in bovine zygotes. Hum. Reprod. 2010, 25, 2762-2773. [CrossRef]

105. Aitken, R.J. Reactive oxygen species as mediators of sperm capacitation and pathological damage. Mol. Reprod. Dev. 2017, 84, 1039-1052. [CrossRef] [PubMed]

106. O'Flaherty, C. Redox regulation of mammalian sperm capacitation. Asian J. Androl. 2015, 17, 583-590. [CrossRef] [PubMed]

107. Aitken, R.; Harkiss, D.; Knox, W.; Paterson, M.; Irvine, D. A novel signal transduction cascade in capacitating human spermatozoa characterised by a redox-regulated, cAMP-mediated induction of tyrosine phosphorylation. J. Cell Sci. 1998, 111, 645-656. [CrossRef] [PubMed]

108. Visconti, P.E.; Bailey, J.L.; Moore, G.D.; Pan, D.; Olds-Clarke, P.; Kopf, G.S. Capacitation of mouse spermatozoa. I. Correlation between the capacitation state and protein tyrosine phosphorylation. Development 1995, 121, 1129-1137. [CrossRef]

109. Aitken, R.J.; Ryan, A.L.; Baker, M.A.; McLaughlin, E.A. Redox activity associated with the maturation and capacitation of mammalian spermatozoa. Free Radic. Biol. Med. 2004, 36, 994-1010. [CrossRef]

110. Morado, S.; Cetica, P.; Beconi, M.; Thompson, J.G.; Dalvit, G. Reactive oxygen species production and redox state in parthenogenetic and sperm-mediated bovine oocyte activation. Reproduction 2013, 145, 471-478. [CrossRef]

111. Li, S.; Winuthayanon, W. Oviduct: Roles in fertilization and early embryo development. J. Endocrinol. 2017, 232, R1-R26. [CrossRef]

112. Saleh, R.A.; Agarwal, A.; Nada, E.A.; El-Tonsy, M.H.; Sharma, R.K.; Meyer, A.; Nelson, D.R.; Thomas, A.J. Negative effects of increased sperm DNA damage in relation to seminal oxidative stress in men with idiopathic and male factor infertility. Fertil. Steril. 2003, 79 (Suppl. 3), 1597-1605. [CrossRef]

113. Agarwal, A.; Said, T.M. Oxidative stress, DNA damage and apoptosis in male infertility: A clinical approach. BJU Int. 2005, 95, 503-507. [CrossRef]

114. Sharma, R.; Said, T.; Agarwal, A. Sperm DNA damage and its clinical relevance in assessing reproductive outcome. Asian J. Androl. 2004, 6, 139-148.

115. McPherson, N.O.; Vincent, A.D.; Pacella-Ince, L.; Tremellen, K. Comparison of in vitro fertilisation/intracytoplasmic sperm injection on live birth rates in couples with non-male factor infertility and advanced maternal age. J. Assist. Reprod. Genet. 2021, 38, 669-678. [CrossRef] [PubMed]

116. Agarwal, A.; Saleh, R.A.; Bedaiwy, M.A. Role of reactive oxygen species in the pathophysiology of human reproduction. Fertil. Steril. 2003, 79, 829-843. [CrossRef]

117. Tatone, C.; Carbone, M.; Falone, S.; Aimola, P.; Giardinelli, A.; Caserta, D.; Marci, R.; Pandolfi, A.; Ragnelli, A.; Amicarelli, F. Age-dependent changes in the expression of superoxide dismutases and catalase are associated with ultrastructural modifications in human granulosa cells. Mol. Hum. Reprod. 2006, 12, 655-660. [CrossRef]

118. de Bruin, J.P.; Dorland, M.; Spek, E.R.; Posthuma, G.; van Haaften, M.; Looman, C.W.N.; te Velde, E.R. Age-Related Changes in the Ultrastructure of the Resting Follicle Pool in Human Ovaries1. Biol. Reprod. 2004, 70, 419-424. [CrossRef]

119. Te Velde, E.R.; Pearson, P.L. The variability of female reproductive ageing. Hum. Reprod. Update 2002, 8, 141-154. [CrossRef]

120. Miyamoto, K.; Sato, E.F.; Kasahara, E.; Jikumaru, M.; Hiramoto, K.; Tabata, H.; Katsuragi, M.; Odo, S.; Utsumi, K.; Inoue, M. Effect of oxidative stress during repeated ovulation on the structure and functions of the ovary, oocytes, and their mitochondria. Free Radic. Biol. Med. 2010, 49, 674-681. [CrossRef]

121. Martin, K.L.; Leese, H.J. Role of developmental factors in the switch from pyruvate to glucose as the major exogenous energy substrate in the preimplantation mouse embryo. Reprod. Fertil. Dev. 1999, 11, 425-433. [CrossRef]

122. Houghton, F.D.; Thompson, J.G.; Kennedy, C.J.; Leese, H.J. Oxygen consumption and energy metabolism of the early mouse embryo. Mol. Reprod. Dev. Inc. Gamete Res. 1996, 44, 476-485. [CrossRef]

123. Houghton, F.D.; Leese, H.J. Metabolism and developmental competence of the preimplantation embryo. Eur. J. Obstet. Gynecol. Reprod. Biol. 2004, 115 (Suppl. 1), S92-S96. [CrossRef] [PubMed]

124. Thomas, M.; Jain, S.; Kumar, G.P.; Laloraya, M. A programmed oxyradical burst causes hatching of mouse blastocysts. J. Cell Sci. 1997, 110 Pt 14, 1597-1602. [CrossRef]

125. Bedaiwy, M.; Agarwal, A.; Said, T.M.; Goldberg, J.M.; Sharma, R.K.; Worley, S.; Falcone, T. Role of total antioxidant capacity in the differential growth of human embryos in vitro. Fertil. Steril. 2006, 86, 304-309. [CrossRef]

126. Swain, J.E. Controversies in ART: Can the IVF laboratory influence preimplantation embryo aneuploidy? Reprod. Biomed. Online 2019, 39, 599-607. [CrossRef] [PubMed] 
127. Munné, S.; Alikani, M. Culture-induced chromosome abnormalities: The canary in the mine. Reprod. Biomed. Online 2011, 22, 506-508. [CrossRef] [PubMed]

128. Joo, B.S.; Kim, M.K.; Na, Y.J.; Moon, H.S.; Lee, K.S.; Do Kim, H. The mechanism of action of coculture on embryo development in the mouse model: Direct embryo-to-cell contact and the removal of deleterious components. Fertil. Steril. 2001, 75, 193-199. [CrossRef]

129. Cheong, A.W.; Lee, Y.L.; Liu, W.M.; Yeung, W.S.; Lee, K.F. Oviductal microsomal epoxide hydrolase (EPHX1) reduces reactive oxygen species (ROS) level and enhances preimplantation mouse embryo development. Biol. Reprod. 2009, 81, 126-132. [CrossRef] [PubMed]

130. Matsui, M.; Oshima, M.; Oshima, H.; Takaku, K.; Maruyama, T.; Yodoi, J.; Taketo, M.M. Early embryonic lethality caused by targeted disruption of the mouse thioredoxin gene. Dev. Biol. 1996, 178, 179-185. [CrossRef] [PubMed]

131. Xanthoudakis, S.; Smeyne, R.J.; Wallace, J.D.; Curran, T. The redox/DNA repair protein, Ref-1, is essential for early embryonic development in mice. Proc. Natl. Acad. Sci. USA 1996, 93, 8919-8923. [CrossRef] [PubMed]

132. Kuscu, N.; Gungor-Ordueri, N.E.; Sozen, B.; Adiguzel, D.; Celik-Ozenci, C. FoxO transcription factors 1 regulate mouse preimplantation embryo development. J. Assist. Reprod. Genet. 2019, 36, 2121-2133. [CrossRef] [PubMed]

133. Kehrer, J.P. The Haber-Weiss reaction and mechanisms of toxicity. Toxicology 2000, 149, 43-50. [CrossRef]

134. Noda, Y.; Matsumoto, H.; Umaoka, Y.; Tatsumi, K.; Kishi, J.; Mori, T. Involvement of superoxide radicals in the mouse two-cell block. Mol. Reprod. Dev. 1991, 28, 356-360. [CrossRef]

135. Legge, M.; Sellens, M.H. Free radical scavengers ameliorate the 2-cell block in mouse embryo culture. Hum. Reprod. 1991, 6, 867-871. [CrossRef] [PubMed]

136. Gardner, D.K.; Lane, M. Alleviation of the'2-cell block'and development to the blastocyst of CF1 mouse embryos: Role of amino acids, EDTA and physical parameters. Hum. Reprod. 1996, 11, 2703-2712. [CrossRef]

137. Hu, D.B.; Li, Z.S.; Ali, I.; Xu, L.J.; Fang, N.Z. Effect of potential role of p53 on embryo development arrest induced by $\mathrm{H} 2 \mathrm{O} 2$ in mouse. In Vitro Cell. Dev. Biol. Anim. 2017, 53, 344-353. [CrossRef] [PubMed]

138. Cebral, E.; Carrasco, I.; Vantman, D.; Smith, R. Preimplantation embryotoxicity after mouse embryo exposition to reactive oxygen species. Biocell 2007, 31, 51-59. [CrossRef]

139. Gardiner, C.S.; Reed, D.J. Status of glutathione during oxidant-induced oxidative stress in the preimplantation mouse embryo. Biol. Reprod. 1994, 51, 1307-1314. [CrossRef] [PubMed]

140. Ozawa, M.; Nagai, T.; Fahrudin, M.; Karja, N.W.; Kaneko, H.; Noguchi, J.; Ohnuma, K.; Kikuchi, K. Addition of glutathione or thioredoxin to culture medium reduces intracellular redox status of porcine IVM/IVF embryos, resulting in improved development to the blastocyst stage. Mol. Reprod. Dev. 2006, 73, 998-1007. [CrossRef]

141. Sun, W.J.; Pang, Y.W.; Liu, Y.; Hao, H.S.; Zhao, X.M.; Qin, T.; Zhu, H.B.; Du, W.H. Exogenous glutathione supplementation in culture medium improves the bovine embryo development after in vitro fertilization. Theriogenology 2015, 84, 716-723. [CrossRef]

142. Brütsch, S.H.; Wang, C.C.; Li, L.; Stender, H.; Neziroglu, N.; Richter, C.; Kuhn, H.; Borchert, A. Expression of inactive glutathione peroxidase 4 leads to embryonic lethality, and inactivation of the Alox15 gene does not rescue such knock-in mice. Antioxid. Redox Signal. 2015, 22, 281-293. [CrossRef]

143. Dalton, T.P.; Dieter, M.Z.; Yang, Y.; Shertzer, H.G.; Nebert, D.W. Knockout of the mouse glutamate cysteine ligase catalytic subunit (Gclc) gene: Embryonic lethal when homozygous, and proposed model for moderate glutathione deficiency when heterozygous. Biochem. Biophys. Res. Commun. 2000, 279, 324-329. [CrossRef]

144. Winkler, A.; Njålsson, R.; Carlsson, K.; Elgadi, A.; Rozell, B.; Abraham, L.; Ercal, N.; Shi, Z.-Z.; Lieberman, M.W.; Larsson, A. Glutathione is essential for early embryogenesis-analysis of a glutathione synthetase knockout mouse. Biochem. Biophys. Res. Commun. 2011, 412, 121-126. [CrossRef]

145. Zhang, H.M.; Zhang, Y. Melatonin: A well-documented antioxidant with conditional pro-oxidant actions. J. Pineal Res. 2014, 57, 131-146. [CrossRef]

146. Pang, Y.-w.; Jiang, X.-l.; Zhao, S.-j.; Huang, Z.-q.; Zhu, H.-b. Beneficial role of melatonin in protecting mammalian gametes and embryos from oxidative damage. J. Integr. Agric. 2018, 17, 2320-2335. [CrossRef]

147. Tamura, H.; Takasaki, A.; Taketani, T.; Tanabe, M.; Kizuka, F.; Lee, L.; Tamura, I.; Maekawa, R.; Aasada, H.; Yamagata, Y.; et al. The role of melatonin as an antioxidant in the follicle. J. Ovarian Res. 2012, 5, 5. [CrossRef]

148. Tamura, H.; Takasaki, A.; Miwa, I.; Taniguchi, K.; Maekawa, R.; Asada, H.; Taketani, T.; Matsuoka, A.; Yamagata, Y.; Shimamura, K. Oxidative stress impairs oocyte quality and melatonin protects oocytes from free radical damage and improves fertilization rate. J. Pineal Res. 2008, 44, 280-287. [CrossRef]

149. Gao, C.; Han, H.B.; Tian, X.Z.; Tan, D.X.; Wang, L.; Zhou, G.B.; Zhu, S.E.; Liu, G.S. Melatonin promotes embryonic development and reduces reactive oxygen species in vitrified mouse 2-cell embryos. J. Pineal Res. 2012, 52, 305-311. [CrossRef]

150. Kitagawa, Y.; Suzuki, K.; Yoneda, A.; Watanabe, T. Effects of oxygen concentration and antioxidants on the in vitro developmental ability, production of reactive oxygen species (ROS), and DNA fragmentation in porcine embryos. Theriogenology 2004, 62, 1186-1197. [CrossRef]

151. Hossein, M.S.; Hashem, M.A.; Jeong, Y.W.; Lee, M.S.; Kim, S.; Kim, J.H.; Koo, O.J.; Park, S.M.; Lee, E.G.; Park, S.W.; et al. Temporal effects of alpha-tocopherol and L-ascorbic acid on in vitro fertilized porcine embryo development. Anim. Reprod. Sci. 2007, 100, 107-117. [CrossRef] [PubMed] 
152. Wang, X.; Falcone, T.; Attaran, M.; Goldberg, J.M.; Agarwal, A.; Sharma, R.K. Vitamin C and vitamin E supplementation reduce oxidative stress-induced embryo toxicity and improve the blastocyst development rate. Fertil. Steril. 2002, 78, $1272-1277$. [CrossRef]

153. Lin, T.; Lee, J.E.; Kang, J.W.; Shin, H.Y.; Lee, J.B.; Jin, D.I. Endoplasmic Reticulum (ER) Stress and Unfolded Protein Response (UPR) in Mammalian Oocyte Maturation and Preimplantation Embryo Development. Int. J. Mol. Sci. 2019, 20, 1-19. [CrossRef] [PubMed]

154. Zhang, J.Y.; Diao, Y.F.; Kim, H.R.; Jin, D.I. Inhibition of endoplasmic reticulum stress improves mouse embryo development. PLoS ONE 2012, 7, e40433. [CrossRef]

155. Kang, M.H.; Das, J.; Gurunathan, S.; Park, H.W.; Song, H.; Park, C.; Kim, J.H. The cytotoxic effects of dimethyl sulfoxide in mouse preimplantation embryos: A mechanistic study. Theranostics 2017, 7, 4735-4752. [CrossRef]

156. Yoon, S.B.; Choi, S.A.; Sim, B.W.; Kim, J.S.; Mun, S.E.; Jeong, P.S.; Yang, H.J.; Lee, Y.; Park, Y.H.; Song, B.S.; et al. Developmental competence of bovine early embryos depends on the coupled response between oxidative and endoplasmic reticulum stress. Biol. Reprod. 2014, 90, 104. [CrossRef]

157. Mao, T.; Han, C.; Wei, B.; Zhao, L.; Zhang, Q.; Deng, R.; Liu, J.; Luo, Y.; Zhang, Y. Protective effects of quercetin against cadmium chloride-induced oxidative injury in goat sperm and zygotes. Biol. Trace Elem. Res. 2018, 185, 344-355. [CrossRef] [PubMed]

158. Fakruzzaman, M.; Ghanem, N.; Bang, J.-I.; Ha, A.-N.; Lee, K.-L.; Sohn, S.-H.; Wang, Z.; Lee, D.-S.; Kong, I.-K. Effect of peroxiredoxin II on the quality and mitochondrial activity of pre-implantation bovine embryos. Anim. Reprod. Sci. 2015, 159, 172-183. [CrossRef] [PubMed]

159. Zhang, W.; Lv, J.; Zhang, Y.; Jiang, Y.; Chu, C.; Wang, S. Epigallocatechin Gallate Promotes the Development of Mouse 2-Cell Embryos In Vitro by Regulating Mitochondrial Activity and Expression of Genes Related to p53 Signalling Pathway. Basic Clin. Pharmacol. Toxicol. 2014, 115, 403-410. [CrossRef] [PubMed]

160. Huang, K.; Li, C.; Gao, F.; Fan, Y.; Zeng, F.; Meng, L.; Li, L.; Zhang, S.; Wei, H. Epigallocatechin-3-Gallate Promotes the in vitro Maturation and Embryo Development Following IVF of Porcine Oocytes. Drug Des. Dev. Ther. 2021, 15, 1013-1020. [CrossRef]

161. Gardner, D.; Leese, H. Concentrations of nutrients in mouse oviduct fluid and their effects on embryo development and metabolism in vitro. Reproduction 1990, 88, 361-368. [CrossRef]

162. Treleaven, T.; Hardy, M.L.M.; Guttman-Jones, M.; Morris, M.B.; Day, M.L. In Vitro Fertilisation of Mouse Oocytes in L-Proline and L-Pipecolic Acid Improves Subsequent Development. Cells 2021, 10, 1-16. [CrossRef]

163. Morris, M.B.; Ozsoy, S.; Zada, M.; Zada, M.; Zamfirescu, R.C.; Todorova, M.G.; Day, M.L. Selected Amino Acids Promote Mouse Pre-implantation Embryo Development in a Growth Factor-Like Manner. Front. Physiol. 2020, 11, 140. [CrossRef]

164. Morbeck, D.E.; Krisher, R.L.; Herrick, J.R.; Baumann, N.A.; Matern, D.; Moyer, T. Composition of commercial media used for human embryo culture. Fertil. Steril. 2014, 102, 759-766. [CrossRef]

165. Krishnan, N.; Dickman, M.B.; Becker, D.F. Proline modulates the intracellular redox environment and protects mammalian cells against oxidative stress. Free Radic. Biol. Med. 2008, 44, 671-681. [CrossRef]

166. Liang, X.; Zhang, L.; Natarajan, S.K.; Becker, D.F. Proline mechanisms of stress survival. Antioxid. Redox Signal. 2013, 19, 998-1011. [CrossRef]

167. Holtzapple, P.; Genel, M.; Rea, C.; Segal, S. Metabolism and uptake of l-proline by human kidney cortex. Pediatr. Res. 1973, 7, 818-825. [CrossRef] [PubMed]

168. Wang, J.; Xue, Z.; Hua, C.; Lin, J.; Shen, Z.; Song, Y.; Ying, H.; Lv, Q.; Wang, M.; Zhou, B. Metabolomic Analysis of the Ameliorative Effect of Enhanced Proline Metabolism on Hypoxia-Induced Injury in Cardiomyocytes. Oxid. Med. Cell. Longev. 2020, 2020, 8866946. [CrossRef]

169. Liu, N.; Yang, Y.; Si, X.; Jia, H.; Zhang, Y.; Jiang, D.; Dai, Z.; Wu, Z. L-Proline Activates Mammalian Target of Rapamycin Complex 1 and Modulates Redox Environment in Porcine Trophectoderm Cells. Biomolecules 2021, 11, 1-11. [CrossRef]

170. Adams, E. Metabolism of proline and of hydroxyproline. Int. Rev. Connect. Tissue Res. 1970, 5, 1-91. [CrossRef] [PubMed]

171. Feng, C.; Zhu, Z.; Bai, W.; Li, R.; Zheng, Y.; Tian, X.e.; Wu, D.; Lu, H.; Wang, Y.; Zeng, W. Proline Protects Boar Sperm against Oxidative Stress through Proline Dehydrogenase-Mediated Metabolism and the Amine Structure of Pyrrolidine. Animals 2020, 10, 1-16. [CrossRef]

172. Suzuki, C.; Yoshioka, K.; Sakatani, M.; Takahashi, M. Glutamine and hypotaurine improves intracellular oxidative status and in vitro development of porcine preimplantation embryos. Zygote 2007, 15, 317-324. [CrossRef]

173. Guerin, P.; Menezo, Y. Hypotaurine and taurine in gamete and embryo environments: De novo synthesis via the cysteine sulfinic acid pathway in oviduct cells. Zygote 1995, 3, 333-343. [CrossRef]

174. Anchordoquy, J.P.; Lizarraga, R.M.; Anchordoquy, J.M.; Nikoloff, N.; Rosa, D.E.; Fabra, M.C.; Peral-Garcia, P.; Furnus, C.C. Effect of cysteine, glutamate and glycine supplementation to in vitro fertilization medium during bovine early embryo development. Reprod. Biol. 2019, 19, 349-355. [CrossRef]

175. Bahrami, M.; Morris, M.B.; Day, M.L. Amino acid supplementation of a simple inorganic salt solution supports efficient in vitro maturation (IVM) of bovine oocytes. Sci. Rep. 2019, 9, 1-10. [CrossRef]

176. Das, K.C.; Misra, H.P. Hydroxyl radical scavenging and singlet oxygen quenching properties of polyamines. Mol. Cell. Biochem. 2004, 262, 127-133. [CrossRef]

177. Lefevre, P.L.; Palin, M.F.; Murphy, B.D. Polyamines on the reproductive landscape. Endocr. Rev. 2011, 32, 694-712. [CrossRef] 
178. Chirino-Galindo, G.; Mejia-Zepeda, R.; Palomar-Morales, M. Change in lipoperoxidation but not in scavenging enzymes activity during polyamine embryoprotection in rat embryo cultured in hyperglycemic media. In Vitro Cell. Dev. Biol. Anim. 2012, 48, 570-576. [CrossRef] [PubMed]

179. Jin, J.X.; Lee, S.; Khoirinaya, C.; Oh, A.; Kim, G.A.; Lee, B.C. Supplementation with spermine during in vitro maturation of porcine oocytes improves early embryonic development after parthenogenetic activation and somatic cell nuclear transfer. $J$. Anim. Sci. 2016, 94, 963-970. [CrossRef] [PubMed]

180. Liu, N.; Dai, Z.; Zhang, Y.; Jia, H.; Chen, J.; Sun, S.; Wu, G.; Wu, Z. Maternal l-proline supplementation during gestation alters amino acid and polyamine metabolism in the first generation female offspring of C57BL/6J mice. Amino Acids 2019, 51, 805-811. [CrossRef]

181. Wu, G.; Bazer, F.W.; Hu, J.; Johnson, G.A.; Spencer, T.E. Polyamine synthesis from proline in the developing porcine placenta. Biol. Reprod. 2005, 72, 842-850. [CrossRef] [PubMed]

182. Leite, R.F.; Annes, K.; Ispada, J.; de Lima, C.B.; Dos Santos, E.C.; Fontes, P.K.; Nogueira, M.F.G.; Milazzotto, M.P. Oxidative Stress Alters the Profile of Transcription Factors Related to Early Development on In Vitro Produced Embryos. Oxid. Med. Cell. Longev. 2017, 2017, 1502489. [CrossRef]

183. Amin, A.; Gad, A.; Salilew-Wondim, D.; Prastowo, S.; Held, E.; Hoelker, M.; Rings, F.; Tholen, E.; Neuhoff, C.; Looft, C. Bovine embryo survival under oxidative-stress conditions is associated with activity of the NRF2-mediated oxidative-stress-response pathway. Mol. Reprod. Dev. 2014, 81, 497-513. [CrossRef]

184. Belli, M.; Zhang, L.; Liu, X.; Donjacour, A.; Ruggeri, E.; Palmerini, M.G.; Nottola, S.A.; Macchiarelli, G.; Rinaudo, P. Oxygen concentration alters mitochondrial structure and function in in vitro fertilized preimplantation mouse embryos. Hum. Reprod. 2019, 34, 601-611. [CrossRef] [PubMed]

185. Qian, D.; Li, Z.; Zhang, Y.; Huang, Y.; Wu, Q.; Ru, G.; Chen, M.; Wang, B. Response of Mouse Zygotes Treated with Mild Hydrogen Peroxide as a Model to Reveal Novel Mechanisms of Oxidative Stress-Induced Injury in Early Embryos. Oxid. Med. Cell. Longev. 2016, 2016, 1521428. [CrossRef]

186. Dennery, P.A. Effects of oxidative stress on embryonic development. Birth Defects Res. C Embryo Today 2007, 81, 155-162. [CrossRef] [PubMed]

187. de Waal, E.; Mak, W.; Calhoun, S.; Stein, P.; Ord, T.; Krapp, C.; Coutifaris, C.; Schultz, R.M.; Bartolomei, M.S. In vitro culture increases the frequency of stochastic epigenetic errors at imprinted genes in placental tissues from mouse concepti produced through assisted reproductive technologies. Biol. Reprod. 2014, 90, 22. [CrossRef] [PubMed]

188. Harvey, A.J.; Kind, K.L.; Pantaleon, M.; Armstrong, D.T.; Thompson, J.G. Oxygen-regulated gene expression in bovine blastocysts. Biol. Reprod. 2004, 71, 1108-1119. [CrossRef]

189. Rinaudo, P.F.; Giritharan, G.; Talbi, S.; Dobson, A.T.; Schultz, R.M. Effects of oxygen tension on gene expression in preimplantation mouse embryos. Fertil. Steril. 2006, 86, 1252-1265. [CrossRef] [PubMed]

190. Harvey, A.J. The role of oxygen in ruminant preimplantation embryo development and metabolism. Anim. Reprod. Sci. 2007, 98, 113-128. [CrossRef]

191. Bontekoe, S.; Mantikou, E.; van Wely, M.; Seshadri, S.; Repping, S.; Mastenbroek, S. Low oxygen concentrations for embryo culture in assisted reproductive technologies. Cochrane Database Syst. Rev. 2012. [CrossRef]

192. Christianson, M.S.; Zhao, Y.; Shoham, G.; Granot, I.; Safran, A.; Khafagy, A.; Leong, M.; Shoham, Z. Embryo catheter loading and embryo culture techniques: Results of a worldwide Web-based survey. J. Assist. Reprod. Genet. 2014, 31, 1029-1036. [CrossRef]

193. Ma, Y.Y.; Chen, H.W.; Tzeng, C.R. Low oxygen tension increases mitochondrial membrane potential and enhances expression of antioxidant genes and implantation protein of mouse blastocyst cultured in vitro. J. Ovarian Res. 2017, 10, 47. [CrossRef]

194. Peng, Z.F.; Shi, S.L.; Jin, H.X.; Yao, G.D.; Wang, E.Y.; Yang, H.Y.; Song, W.Y.; Sun, Y.P. Impact of oxygen concentrations on fertilization, cleavage, implantation, and pregnancy rates of in vitro generated human embryos. Int. J. Clin. Exp. Med. 2015, 8, 6179-6185.

195. Du Plessis, S.S.; Makker, K.; Desai, N.R.; Agarwal, A. Impact of oxidative stress on IVF. Expert Rev. Obstet. Gynecol. 2008, 3, 539-554. [CrossRef]

196. Pabon Jr, J.E.; Findley, W.E.; Gibbons, W.E. The toxic effect of short exposures to the atmospheric oxygen concentration on early mouse embryonic development. Fertil. Steril. 1989, 51, 896-900. [CrossRef]

197. Takenaka, M.; Horiuchi, T.; Yanagimachi, R. Effects of light on development of mammalian zygotes. Proc. Natl. Acad. Sci. USA 2007, 104, 14289-14293. [CrossRef] [PubMed]

198. Bognar, Z.; Csabai, T.J.; Pallinger, E.; Balassa, T.; Farkas, N.; Schmidt, J.; Gorgey, E.; Berta, G.; Szekeres-Bartho, J.; Bodis, J. The effect of light exposure on the cleavage rate and implantation capacity of preimplantation murine embryos. J. Reprod. Immunol. 2019, 132, 21-28. [CrossRef]

199. Agarwal, A.; Durairajanayagam, D.; du Plessis, S.S. Utility of antioxidants during assisted reproductive techniques: An evidence based review. Reprod. Biol. Endocrinol. 2014, 12, 112. [CrossRef] [PubMed]

200. Feuer, S.; Rinaudo, P. From embryos to adults: A DOHaD perspective on in vitro fertilization and other assisted reproductive technologies. Healthcare 2016, 4, 1-13. [CrossRef] [PubMed]

201. Menezo, Y.; Clement, P.; Dale, B.; Elder, K. Modulating oxidative stress and epigenetic homeostasis in preimplantation IVF embryos. Zygote 2021, 1-10. [CrossRef] 
202. Zhang, J.; Wang, X.; Vikash, V.; Ye, Q.; Wu, D.; Liu, Y.; Dong, W. ROS and ROS-Mediated Cellular Signaling. Oxid. Med. Cell. Longev. 2016, 2016, 4350965. [CrossRef]

203. Delic, V.; Griffin, J.W.D.; Zivkovic, S.; Zhang, Y.; Phan, T.A.; Gong, H.; Chaput, D.; Reynes, C.; Dinh, V.B.; Cruz, J.; et al. Individual Amino Acid Supplementation Can Improve Energy Metabolism and Decrease ROS Production in Neuronal Cells Overexpressing Alpha-Synuclein. Neuromolecular Med. 2017, 19, 322-344. [CrossRef]

204. Ding, Z.-M.; Jiao, X.-F.; Wu, D.; Zhang, J.-Y.; Chen, F.; Wang, Y.-S.; Huang, C.-J.; Zhang, S.-X.; Li, X.; Huo, L.-J. Bisphenol AF negatively affects oocyte maturation of mouse in vitro through increasing oxidative stress and DNA damage. Chem. Biol. Interact. 2017, 278, 222-229. [CrossRef] [PubMed]

205. Xin, F.; Susiarjo, M.; Bartolomei, M.S. Multigenerational and transgenerational effects of endocrine disrupting chemicals: A role for altered epigenetic regulation? Semin. Cell Dev. Biol. 2015, 43, 66-75. [CrossRef] [PubMed]

206. Chianese, R.; Pierantoni, R. Mitochondrial Reactive Oxygen Species (ROS) Production Alters Sperm Quality. Antioxidants 2021, 10, 92. [CrossRef] [PubMed]

207. Drevet, J.R.; Aitken, R.J. Oxidation of Sperm Nucleus in Mammals: A Physiological Necessity to Some Extent with Adverse Impacts on Oocyte and Offspring. Antioxidants 2020, 9, 1-14. [CrossRef]

208. Edwards, R.G.; Ludwig, M. Are major defects in children conceived in vitro due to innate problems in patients or to induced genetic damage? Reprod. Biomed. Online 2003, 7, 131-138. [CrossRef]

209. Nishihara, T.; Hashimoto, S.; Ito, K.; Nakaoka, Y.; Matsumoto, K.; Hosoi, Y.; Morimoto, Y. Oral melatonin supplementation improves oocyte and embryo quality in women undergoing in vitro fertilization-embryo transfer. Gynecol. Endocrinol. 2014, 30, 359-362. [CrossRef] [PubMed]

210. Batioglu, A.S.; Sahin, U.; Gurlek, B.; Ozturk, N.; Unsal, E. The efficacy of melatonin administration on oocyte quality. Gynecol. Endocrinol. 2012, 28, 91-93. [CrossRef]

211. Espino, J.; Macedo, M.; Lozano, G.; Ortiz, A.; Rodriguez, C.; Rodriguez, A.B.; Bejarano, I. Impact of Melatonin Supplementation in Women with Unexplained Infertility Undergoing Fertility Treatment. Antioxidants 2019, 8, 1-11. [CrossRef]

212. Pacchiarotti, A.; Carlomagno, G.; Antonini, G.; Pacchiarotti, A. Effect of myo-inositol and melatonin versus myo-inositol, in a randomized controlled trial, for improving in vitro fertilization of patients with polycystic ovarian syndrome. Gynecol. Endocrinol. 2016, 32, 69-73. [CrossRef]

213. Hasan, A.; Elena, A.-Q.; Ghassan, A.-Q.; Rimawi, T.; Nasrallah, S. Melatonin and Myoinositol: A Foreword Step Toward IVF Success, a Prospective Clinical Trial. J. Gynecol. Obstet. 2019, 7, 1-7. [CrossRef]

214. Xu, Y.; Nisenblat, V.; Lu, C.; Li, R.; Qiao, J.; Zhen, X.; Wang, S. Pretreatment with coenzyme Q10 improves ovarian response and embryo quality in low-prognosis young women with decreased ovarian reserve: A randomized controlled trial. Reprod. Biol. Endocrinol. 2018, 16, 29. [CrossRef] [PubMed]

215. Giannubilo, S.R.; Orlando, P.; Silvestri, S.; Cirilli, I.; Marcheggiani, F.; Ciavattini, A.; Tiano, L. CoQ10 Supplementation in Patients Undergoing IVF-ET: The Relationship with Follicular Fluid Content and Oocyte Maturity. Antioxidants 2018, 7, 1-12. [CrossRef]

216. Gat, I.; Blanco Mejia, S.; Balakier, H.; Librach, C.L.; Claessens, A.; Ryan, E.A. The use of coenzyme Q10 and DHEA during IUI and IVF cycles in patients with decreased ovarian reserve. Gynecol. Endocrinol. 2016, 32, 534-537. [CrossRef] [PubMed]

217. Gong, Y.; Luo, S.; Fan, P.; Jin, S.; Zhu, H.; Deng, T.; Quan, Y.; Huang, W. Growth hormone alleviates oxidative stress and improves oocyte quality in Chinese women with polycystic ovary syndrome: A randomized controlled trial. Sci. Rep. 2020, 10, 18769. [CrossRef]

218. Salehpour, S.; Akbari Sene, A.; Saharkhiz, N.; Sohrabi, M.R.; Moghimian, F. N-acetylcysteine as an adjuvant to clomiphene citrate for successful induction of ovulation in infertile patients with polycystic ovary syndrome. J. Obstet. Gynaecol. Res. 2012, 38, 1182-1186. [CrossRef] [PubMed]

219. Ozkaya, M.O.; Naziroglu, M. Multivitamin and mineral supplementation modulates oxidative stress and antioxidant vitamin levels in serum and follicular fluid of women undergoing in vitro fertilization. Fertil. Steril. 2010, 94, 2465-2466. [CrossRef] [PubMed]

220. Kacem, O.; Harzallah, M.; Zedini, C.; Zidi, I.; Meddeb, S.; Fékih, M.; Saidi, H.; Chaib, A.; Boughizane, S.; Ali, H.B.; et al. Beneficial Effect of an Oral Antioxidant Supplementation (Fertimax2) on IVF-ICSI Outcomes: A Preliminary Clinical Study. Adv. Reprod. Sci. 2014, 2, 47-56. [CrossRef]

221. Tremellen, K.; Miari, G.; Froiland, D.; Thompson, J. A randomised control trial examining the effect of an antioxidant (Menevit) on pregnancy outcome during IVF-ICSI treatment. Aust. N. Z. J. Obstet. Gynaecol. 2007, 47, 216-221. [CrossRef]

222. Luddi, A.; Capaldo, A.; Focarelli, R.; Gori, M.; Morgante, G.; Piomboni, P.; De Leo, V. Antioxidants reduce oxidative stress in follicular fluid of aged women undergoing IVF. Reprod. Biol. Endocrinol. 2016, 14, 57. [CrossRef] [PubMed]

223. Steiner, A.Z.; Hansen, K.R.; Barnhart, K.T.; Cedars, M.I.; Legro, R.S.; Diamond, M.P.; Krawetz, S.A.; Usadi, R.; Baker, V.L.; Coward, R.M.; et al. The effect of antioxidants on male factor infertility: The Males, Antioxidants, and Infertility (MOXI) randomized clinical trial. Fertil. Steril. 2020, 113, 552-560. [CrossRef]

224. El Nashar, A.; Salama, K.; El-Deen, A.; Fayez, A. Effects of Pentoxifylline and Vitamin E on Pregnancy Rate in Infertile Women Treated By ICSI: A Randomized Clinical Trial. Benha J. Appl. Sci. 2020, 5, 1-6. [CrossRef]

225. Tremellen, K.; Woodman, R.; Hill, A.; Shehadeh, H.; Lane, M.; Zander-Fox, D. Use of a male antioxidant nutraceutical is associated with superior live birth rates during IVF treatment. Asian J. Androl. 2021, 23, 16-23. [CrossRef] [PubMed] 
226. Ruiz, M.; Santamaria-Lopez, E.; Blasco, V.; Hernaez, M.J.; Caligara, C.; Pellicer, A.; Fernandez-Sanchez, M.; Prados, N. Effect of Group Embryo Culture under Low-Oxygen Tension in Benchtop Incubators on Human Embryo Culture: Prospective, Randomized, Controlled Trial. Reprod. Sci. 2020, 27, 1522-1533. [CrossRef] [PubMed]

227. Van Montfoort, A.P.A.; Arts, E.; Wijnandts, L.; Sluijmer, A.; Pelinck, M.J.; Land, J.A.; Van Echten-Arends, J. Reduced oxygen concentration during human IVF culture improves embryo utilization and cumulative pregnancy rates per cycle. Hum. Reprod. Open 2020, 2020, hoz036. [CrossRef]

228. Gelo, N.; Kirinec, G.; Baldani, D.P.; Vrcic, H.; Jezek, D.; Milosevic, M.; Stanic, P. Influence of human embryo cultivation in a classic $\mathrm{CO} 2$ incubator with $20 \%$ oxygen versus benchtop incubator with $5 \%$ oxygen on live births: The randomized prospective trial. Zygote 2019, 27, 131-136. [CrossRef] [PubMed]

229. Aleyasin, A.; Aghahosseini, M.; Mohseni, M.; Mahdavi, A. Effects of pentoxifylline and vitamin E on pregnancy rate in infertile women treated by ZIFT: A randomized clinical trial. Int. J. Reprod. BioMedicine 2009, 7, 170-175.

230. Gardner, D.K.; Kuramoto, T.; Tanaka, M.; Mitzumoto, S.; Montag, M.; Yoshida, A. Prospective randomized multicentre comparison on sibling oocytes comparing G-Series media system with antioxidants versus standard G-Series media system. Reprod. Biomed. Online 2020, 40, 637-644. [CrossRef]

231. Kim, M.K.; Park, J.K.; Paek, S.K.; Kim, J.W.; Kwak, I.P.; Lee, H.J.; Lyu, S.W.; Lee, W.S. Effects and pregnancy outcomes of L-carnitine supplementation in culture media for human embryo development from in vitro fertilization. J. Obstet. Gynaecol. Res. 2018, 44, 2059-2066. [CrossRef]

232. Ma, L.; Cai, L.; Hu, M.; Wang, J.; Xie, J.; Xing, Y.; Shen, J.; Cui, Y.; Liu, X.J.; Liu, J. Coenzyme Q10 supplementation of human oocyte in vitro maturation reduces postmeiotic aneuploidies. Fertil. Steril. 2020, 114, 331-337. [CrossRef]

233. Fabozzi, G.; Albricci, L.; Cimadomo, D.; Amendola, M.G.; Sanges, F.; Maggiulli, R.; Ubaldi, F.M.; Rienzi, L. Blastulation rates of sibling oocytes in two IVF culture media: An evidence-based workflow to implement newly commercialized products. Reprod. Biomed. Online 2021, 42, 311-322. [CrossRef]

234. Taherian, S.S.; Khayamabed, R.; Tavalaee, M.; Nasr-Esfahani, M.H. Alpha-lipoic acid minimises reactive oxygen species-induced damages during sperm processing. Andrologia 2019, 51, e13314. [CrossRef] [PubMed]

235. Zhang, W.; Li, F.; Cao, H.; Li, C.; Du, C.; Yao, L.; Mao, H.; Lin, W. Protective effects of l-carnitine on astheno- and normozoospermic human semen samples during cryopreservation. Zygote 2016, 24, 293-300. [CrossRef] [PubMed] 